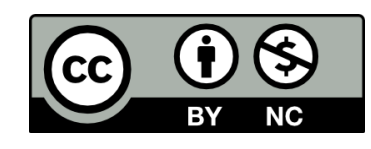

\title{
Designing the Montessori Coaching Tool Elementary Rubric for Early-Career Professional Development
}

\author{
Angela K. Murray, University of Kansas \\ Carolyn J. Daoust, University of Kansas \\ Jan Mallett, Southern Methodist University \\ Sharon Damore, Guest Editor
}

Keywords: Montessori; rubric; teacher coaching; elementary education; teacher preparation; rubric development; reflective practice

\begin{abstract}
Becoming a competent Montessori Elementary guide is a complex process, so we are developing the Montessori Coaching Tool Elementary (MCT-EL) rubric to describe teaching-practice expectations for self-reflection and formative feedback during the critical early period in a teacher's development. The purpose of this article is to share results from a small-scale, online survey collecting both qualitative and quantitative feedback on the rubric from experienced Montessori Elementary teacher educators. The rubric's content was based on Maria Montessori's writings and welldocumented Montessori practices, which we translated to specific teacher behaviors and developmental progressions. We wanted to gauge the MCT-EL rubric's usefulness and appropriateness from the perspective of experts who have significant depth of experience mentoring new teachers. The rubric was not developed to be used for performance evaluation, promotion, or retention but rather for early-career Montessori teachers' self-reflection. It provides a framework for coaching conversations between the early-career Montessori teacher and a Montessori mentor. Results from the study identified overall support for use of the MCT-EL rubric with developing teachers, along with specific recommendations for revisions, additions, and deletions. Using a thorough review of the data, we developed a refined MCT-EL rubric, which is provided in Appendix B and is available for use by interested practitioners in the field.
\end{abstract}

Becoming a competent Montessori Elementary guide requires the development of specific skills and competencies that represent quality practice. What proficiencies make up this skill set, and how might these develop over time? We are developing the Montessori Coaching Tool Elementary (MCT-EL) rubric to describe teaching-practice expectations for self-reflection and formative feedback during the critical early period in an Elementary teacher's development.

The content of the MCT-EL rubric was based on Maria Montessori's writings and well-documented Montessori practices (see Tables 1 and 2). 
Acknowledging the diversity of Montessori training experiences and practices in the field, this rubric provides a valuable framework, rooted in a sound research base, for supporting the development of high-quality Montessori Elementary teachers. We envisioned coaching sessions based on the MCT-EL rubric framework over time that would trace a teacher's growth trajectory and encourage reflection on and refinement of their practice. The rubric maps the progression of teacher growth from an initial lack of awareness of Montessori best practices to a beginning level of proficiency to developing, maturing, and integrating their implementation of these skills over time. The MCT-EL rubric was not developed with the intention for use in performance evaluation, promotion, or retention, and no scores are attached to any section of the rubric. Instead, the rubric was designed to be used by early-career Montessori teachers for self-reflection and as a basis for coaching conversations between early-career Montessori teachers and their mentors. The purpose of this article is to discuss the results of a research study investigating the utility of this rubric using feedback from experienced Montessori Elementary teacher educators.

\section{Literature Review}

A discussion of the literature provides important context for the development of the rubric and the design of this study. We start with an introduction to teacher coaching and the development and use of rubrics in educational settings in general. Next, we provide an overview of professional-development efforts using rubrics with Montessori educators and make the case for why a Montessori-specific teacher coaching rubric is necessary.

\section{Coaching Outside of Montessori Settings}

The MCT-EL rubric is intended to provide preservice and early-career Montessori teachers a structured opportunity for self-reflection, leading to collaborative conversations with instructional coaches to improve their teaching practice. Therefore, it is valuable to first examine the use of similar rubrics outside the field of Montessori education. When carefully constructed, thoughtfully implemented, and piloted, coaching sessions are opportunities for formative assessment. Specifically, supportive protocols that are inquiry based can serve as valuable resources for these sessions. Multiple researchers have found evidence that coaching experiences produce positive impacts in both teacher confidence and demonstrated teaching effectiveness (Bartolome, 2017; Elish-Piper \& L’Allier, 2011; Kraft \& Blazar, 2017; Vernon-Feagans et al., 2013). A recent meta-analysis examined the empirical literature on teacher coaching to gauge the effect of coaching programs on instructional practices and student achievement (Kraft et al., 2018). Across 60 studies with causal research designs, the authors found that the impact of teacher coaching as a tool for professional development is favorable; however, they also identified that scaling up such programs is a significant challenge (Kraft et al., 2018).

\section{Rubric Use Outside of Montessori Settings}

Rubrics are commonly used as a tool to facilitate the coaching process (Gulikers et al., 2021; Tchekmedyian et al., 2017; Zugelder et al., 2019). According to Brookhart (2013), "a rubric is a coherent set of criteria for students' work that includes descriptions of levels of performance quality on the criteria” (p. 4). Rubrics are designed to support unbiased observation through providing a structure that shifts the focus from judging performance to simply describing performance, facilitating constructive feedback. Despite empirical evidence that supports the effectiveness of rubrics in enhancing student learning and performance, rubrics have faced criticism for potentially being harmful when poorly designed or implemented. Panadero and Jonsson's (2020) critical review of rubrics argued that this problem largely stems from narrow conceptualizations of rubrics or anecdotal personal experience rather than rigorous research. Instead, they asserted the evidence points to the value of rubrics when implemented effectively for their intended purpose. They further suggested that scientific, empirical research is necessary to optimize the design and use of rubrics.

\section{Assessing Validity in Rubric Development}

Any tool used for either formative or summative assessment, including a rubric, requires validity evidence that it is appropriate for its intended application (American Educational Research Association [AERA] et al., 2014). Authors typically engage in a multistep process to make the case for the validity of rubrics they develop (Allen \& Knight, 2009; Timmerman et al., 2010). Timmerman et al. (2010) provided evidence of the appropriateness of a rubric's content to assess college students' scientific reasoning skills using four sources: 
(a) rubrics in the literature, (b) alignment with criteria used by professional referees for their reviews, (c) input of pedagogical experts, and (d) recursive feedback rounds from stakeholders who were also content experts. Recursive feedback from experts is frequently used to support validity arguments for situations that are not well defined or well researched (Feldon, 2007; Linstone \& Turoff, 1975; Miller et al., 2020).

\section{Montessori Elementary Education}

Montessori classrooms across age levels require certified Montessori teachers and include 3-year, mixedage groupings and long blocks of uninterrupted time for children to choose their work from specially designed materials (Culclasure et al., 2019). Dr. Montessori (1971) conceptualized human development in planes, each corresponding to 6 years of growth. She proposed that children experience these phases or planes with each "having its own particular needs" (Montessori, 1971, p. 1). The focus for the present study is Montessori teachers working with children in the 6-to-12-yearold age group. According to the needs Dr. Montessori identified in what Montessorians call the second plane of development, or the Elementary years (ages 6 to 12), Montessori Elementary education has several unique characteristics that include reliance on interactive, smallgroup lessons within a curriculum that is integrated across subject areas, extensive storytelling, significant freedom and responsibility, and activities designed to optimally challenge each student (Culclasure et al., 2019).

\section{Professional Development, Rubrics, and Coaching for Montessori Educators}

Interest in a coaching orientation is growing within the Montessori community. The National Center for Montessori in the Public Sector (NCMPS) reports having "trained and supported more than 500 Montessori Coaches" in their coaches' training program, which provides preparation for working with Montessori educators in the field (NCMPS, 2021, "Support for Coaches" section). Public Montessori in Action is another organization that offers professional development for coaches, with a focus on "providing systems for reflective, child-centered practice that supports the growth and development of adults" (Public Montessori in Action, n.d.).

A variety of rubrics, instruments, and inventories have been developed to support high-quality Montessori implementation. For example, NCMPS has published the Montessori Assessment Playbook that outlines a Reflective Practice Inventory to allow teachers to rate themselves on 22 items using a 5-point Likert scale (NCMPS, 2019). The Playbook also includes a rubric for assessing the attainment of program-level standards and the Teacher Appraisal Instrument, which is a summative assessment of teaching practice (NCMPS, 2019). NCMPS also developed the Developmental Environmental Rating Scale, which is an iPad-based classroom observation rubric for supporting continual improvement by measuring child and adult behaviors as well as environmental attributes associated with executive function, linguistic and cultural fluency, and social fluency and emotional flexibility (NCMPS, 2019). Further, Canzoneri-Golden and King (2020) developed the Culturally Responsive Practice Anti-Bias Anti-Racism Rubric (CRP-ABAR) for Montessori teachers.

Empirical research on professional development for Montessori educators is limited, but two recent studies have examined its impact. Damore and Rieckhoff (2021) created a coaching protocol designed around the development of leadership competencies for Montessori school leaders. The coaching protocol was implemented as a form of professional development, and research on the protocol demonstrated that school leaders believed guided reflection yielded practice improvement both for themselves as school leaders and for the teachers in their schools. Specifically, they found that modeling and encouraging reflective practice should be a priority among leaders' complex administrative roles. The case study conducted by Saylor et al. (2018) examined a program for cocreated professional-development communities for Montessori teachers. Saylor et al. found that a multidimensional professional-development program addressing mindfulness, reflective practice, and teacher-centered mentorship had the potential to improve teachers' perceptions of the effectiveness of their practices.

\section{Need for a Montessori-Specific Coaching Rubric}

The preceding paragraphs illustrate that, although Montessori professional development, rubrics, and coaching initiatives exist, no comprehensive rubric is available for formative assessment that includes specific expectations of Montessori teacher practice that includes descriptions of levels of performance. In addition, because classroom practices and expectations 
for Montessori teachers are quite different from those for conventional teachers, examining research outside of Montessori education is instructive but insufficient (Lillard \& McHugh, 2019a, 2019b). Coaching as an approach to professional development translates to Montessori environments, but the content of that coaching differs because early-career Montessori teachers require guidance on mastering the unique role of teachers in Montessori classrooms (Damore \& Rieckhoff, 2021; Saylor et al., 2018). Edwards et al. (2020) faced a similar task with respect to the development of a rubric for reflective practices in preservice and in-service teachers inspired by the Reggio Emilia approach to documentation. They developed a rubric based on Reggio's pedagogical documentation dimensions as an approach to engage preservice and in-service teachers, who tended to be more accustomed to following standardized curricula, in reflective practices that were not adequately addressed within the conventional educational literature.

The MCT-EL rubric was developed to fill the gap that exists between the literature on teacher coaching and rubric use in conventional settings and the currently available resources for supporting preservice and early-career Montessori teachers. The MCT-EL rubric includes a coherent set of criteria needed for Montessori Elementary teachers to be successful in the classroom, along with specific descriptions of levels of performance quality for each of the criteria. The purpose of this study is to gauge the usefulness and appropriateness of the MCT-EL rubric by obtaining input from a diverse group of experienced Montessori teacher educators. Therefore, three research questions guided the present study:

1. Do Montessori Elementary teacher experts view a coaching or mentoring rubric as valuable?

2. What are the strengths and weaknesses of the rubric that was developed?

3. What improvements to specific elements are necessary to optimize the value of the rubric?

\section{Methods}

To address our research questions, we designed a mixed-methods research study to obtain input from expert Montessori Elementary teacher educators through an anonymous online survey. As is often the case in mixed-methods research, we employed pragmatism as our philosophical foundation because our focus was on the consequences of our research in a real-world application (Creswell \& Plano Clark, 2018). Our survey collected both qualitative and quantitative data using a "questionnaire variant" form of a convergent mixedmethods research design (Creswell \& Plano Clark, 2018, p. 73). In this design, qualitative data are considered an add-on to the survey instrument, which enriches the quantitative-survey findings. This use of qualitative data to supplement quantitative-survey findings contrasts with the approach of a fully qualitative survey as defined by Braun et al. (2020), which relies primarily on the survey as a rich source of contextualized qualitative data.

Our approach to gathering feedback from experts in the field as an initial validation process parallels the procedures followed by Alsina et al. (2017), Van Ginkel et al. (2017), and Furze et al. (2015). Although we did not follow a strict Delphi technique (i.e., multiple interactive rounds of feedback until consensus is reached), we did incorporate an iterative process of gathering input on the MCT-EL rubric (Linstone \& Turoff, 1975). Details of the development of the MCT-EL rubric are discussed in the next section, followed by a description of the research methods employed.

\section{MCT-EL Rubric Development}

An author of the present study initially developed the MCT-EL rubric to facilitate the self-evaluation of practicum students using Montessori and expert writings, research on Montessori implementation, and author experience that included 20 years supervising Montessori preservice teachers and 7 years teaching Upper Elementary. Daoust, one of the authors of this article, conducted a 1-year pilot in an American Montessori Society (AMS, n.d.) teacher education program (TEP) involved student teachers and their supervising teachers to jointly assess progress at the midpoint and end of the student teaching year. Consultants from the TEP used a similar form to evaluate student teachers after a 2-hour observation. Student feedback on the pilot suggested that the form had promise as an effective rubric.

The success of the TEP observation-tool pilot led us to embark on the present study. We reexamined texts with which we were already familiar so we could critically evaluate the content of the observation tool to ascertain its comprehensiveness in terms of key practices that comprise effective Montessori teaching at the Elementary level. Tables 1 and 2 list the specific Montessori and expert writings and other key resources we consulted for 
Table 1

Resources Consulted for Rubric Development (Organizational Criteria and Maria Montessori's Writings)

\begin{tabular}{|c|c|c|}
\hline Source & Author or publisher & Year \\
\hline \multicolumn{3}{|l|}{ Organizational criteria } \\
\hline AMS accreditation standards & AMS & 2018 \\
\hline AMI/USA Montessori school standards & AMI/USA & 2009 \\
\hline AMI Elementary classes: Detailed description & AMI Canada & n.d. \\
\hline Montessori National Curriculum & $\begin{array}{l}\text { Montessori Australia Foundation } \\
\text { Limited }\end{array}$ & 2012 \\
\hline Montessori assessment playbook & NCMPS & 2019 \\
\hline $\begin{array}{l}\text { The authentic American Montessori school: A guide to the self-study, eval- } \\
\text { uation, and accreditation of American schools committed to Montessori } \\
\text { education }\end{array}$ & $\begin{array}{l}\text { Rambusch \& Stoops (AMS \& the } \\
\text { Commission on Elementary } \\
\text { Schools of the Middle States } \\
\text { Association) }\end{array}$ & 1992 \\
\hline \multicolumn{3}{|l|}{ Maria Montessori's writings } \\
\hline Education for a new world & M. Montessori & 1963 \\
\hline $\begin{array}{l}\text { Spontaneous Montessori activity in education: The advanced Montessori } \\
\text { method }\end{array}$ & M. Montessori & 1965 \\
\hline The child in the family & M. Montessori & 1970 \\
\hline Education and peace & M. Montessori & $1949 / 1972$ \\
\hline To educate the human potential & M. Montessori & 1973 \\
\hline From childhood to adolescence & M. Montessori & 1976 \\
\hline The discovery of the child & M. Montessori & $1948 / 1988$ \\
\hline The absorbent mind & M. Montessori & $1949 / 1989$ \\
\hline The child, society, and the world: Unpublished speeches and writings & M. Montessori & 2008 \\
\hline The Montessori Method & M. Montessori & $1912 / 1964$ \\
\hline $\begin{array}{l}\text { Basic ideas of Montessori's educational theory: Extracts from Maria Mon- } \\
\text { tessori's writings and teachings }\end{array}$ & M. Montessori & $1997 \mathrm{a}$ \\
\hline The California lectures of Maria Montessori & M. Montessori & $1997 b$ \\
\hline Education for human development & M. M. Montessori, Jr. & 1976 \\
\hline
\end{tabular}

Note. AMS = American Montessori Society; AMI = American Montessori Internationale; NCMPS = National Center for

Montessori in the Public Sector.

Table 2

Resources Consulted for Rubric Development (Leading Authors, Articles and Other Publications)

\begin{tabular}{|c|c|c|}
\hline (3) & Author or publisher & Year \\
\hline \multicolumn{3}{|l|}{ Leading Montessori authors } \\
\hline Annette Haines: Spokesperson for Montessori values, scholarship, and research & AMI/NAMTA & 2017-2018 \\
\hline Cosmic education: A collection of talks & Baker et al. & 2008 \\
\hline The Montessori controversy & Chattin-McNichols & 1992 \\
\hline An observer's notebook: Learning from children with the observation C.O.R.E. & Epstein & 2012 \\
\hline What is Montessori Elementary? & Kahn & 1995 \\
\hline Montessori: The science behind the genius & A. Lillard & 2017 \\
\hline Montessori today & P. Lillard & 1996 \\
\hline Elementary classroom management: How to implement cosmic education & Pottish-Lewis & 2011 \\
\hline Maria Montessori: Her life and work & Standing & $1957 / 1984$ \\
\hline Articles and publications & & \\
\hline Designing a logic model to inform Montessori research & Culclasure et al. & 2019 \\
\hline $\begin{array}{l}\text { Montessori magnets and charters: Similarities and differences in implementation. } \\
\text { [Poster] }\end{array}$ & Daoust \& Suzuki & 2013 \\
\hline Public Montessori Elementary: Three models of implementation. [Poster] & Daoust \& Suzuki & 2014 \\
\hline Authentic Montessori: The Dottoressa's view at the end of her life (Parts 1 \& 2) & Lillard \& McHugh & 2019 \\
\hline Developing instruments to measure Montessori instructional practices & Murray et al. & 2019 \\
\hline The role of the disciplines for cosmic education & Grazzini & 2010 \\
\hline What we ve learned, and what we're learning & Huneke Stone & 2019 \\
\hline Becoming a scientific observer & MacDonald & 2016 \\
\hline Montessori voices: Guided by nature & NAMTA & 2013 \\
\hline $\begin{array}{l}\text { What is Montessori? A basic guide to the principles, practices, and benefits of a } \\
\text { Montessori education }\end{array}$ & Pendersen \& Pendersen & 2008 \\
\hline Montessori in action: Building resilient Montessori schools & Slade & 2021 \\
\hline Making some changes in teacher training & Wyld & 2019 \\
\hline
\end{tabular}

Note. AMI = American Montessori Internationale; NAMTA = North American Montessori Teachers' Association. 
creating and revising the rubric. The in-depth analysis of the resources resulted in iterative drafts of key items to be included in the MCT-EL rubric. In addition, this analysis resulted in a cycle of drafting and revising the descriptions of the various levels of performance on each of the items.

In the next phase of development, we collected informal feedback on a preliminary version of the MCTEL rubric from participants at gatherings of teacher educators affiliated with the Montessori Accreditation Council for Teacher Education (MACTE) and AMS. Multiple rounds of revisions to the rubric emerged from these informal feedback sessions, resulting in the version of the MCT-EL rubric presented to participants in this study.

\section{Participants}

Our goal was to gather input from experienced Montessori Elementary teacher trainers because they had the extensive knowledge of Montessori practices necessary to provide in-depth feedback on the coaching rubric. The first step in identifying participants was to visit the websites for Association Montessori Internationale (AMI), AMS, and MACTE Elementary TEPs in the United States to examine the qualifications of the Elementary program directors and key Elementary instructors. Required criteria for inclusion in the study included at least five years of Montessori classroom teaching and administrative experience, a history of professional speaking engagements related to Montessori pedagogy, and service in leadership roles within a regional, national, or international Montessori organization. To ensure a wide range of experiences, we also considered potential participants' record of publishing academic articles or professional books, advanced degrees, professional recognition, and experience in public schools. We collected a list of 32 Elementary trainers with appropriate credentials and substantial experience. Next, we collected email addresses from publicly available websites and professional connections to contact these experts, to introduce

Table 3

Profile of Study Participants

\begin{tabular}{|c|c|c|}
\hline $\begin{array}{l}\text { Multiple responses allowed } \\
\text { for credentials and training }\end{array}$ & $N$ & $\%$ \\
\hline \multicolumn{3}{|l|}{ Credentials held (multiple allowed) } \\
\hline Early Childhood & 12 & 75 \\
\hline Elementary & 16 & 100 \\
\hline Adolescent & 2 & 13 \\
\hline Administrator & 4 & 25 \\
\hline \multicolumn{3}{|l|}{ Elementary training received from } \\
\hline American Montessori Internationale & 4 & 25 \\
\hline American Montessori Society & 9 & 56 \\
\hline International Montessori Council & 1 & 6 \\
\hline Montessori Educational Programs International & 1 & 6 \\
\hline Pan American Montessori Society & 1 & 6 \\
\hline Independent & 1 & 6 \\
\hline \multicolumn{3}{|l|}{ Currently training for (multiple allowed) } \\
\hline American Montessori Internationale & 4 & 25 \\
\hline American Montessori Society & 10 & 63 \\
\hline International Montessori Council & 1 & 6 \\
\hline Montessori Educational Programs International & 1 & 6 \\
\hline Independent & 1 & 6 \\
\hline \multicolumn{3}{|l|}{ Years of classroom teaching } \\
\hline$>25$ & 3 & 19 \\
\hline $21-25$ & 2 & 13 \\
\hline $16-20$ & 2 & 13 \\
\hline $11-15$ & 6 & 38 \\
\hline $6-10$ & 3 & 19 \\
\hline \multicolumn{3}{|l|}{ Years as trainer } \\
\hline$>25$ & 9 & 56 \\
\hline $21-25$ & 4 & 25 \\
\hline $16-20$ & 1 & 6 \\
\hline $11-15$ & 1 & 6 \\
\hline $6-10$ & 1 & 6 \\
\hline
\end{tabular}


the study, and to invite participation. Participants acknowledged an information statement before completing the survey, and our procedures were approved by the institutional review board (IRB) at the University of Kansas.

A total of 18 participants responded to the online survey, an excellent response rate of 56\% relative to the range of $20 \%$ to $30 \%$ reported as typical by Qualtrics (n.d.), which hosted the survey. Table 3 profiles the 16 participants who provided background information in the survey. Although two individuals chose not to provide background information, the reported results indicated that participants held the required credentials and had extensive professional experience. All participants had Montessori Elementary training, with half receiving training from AMS and the next-largest group receiving training from AMI. The majority of participants reported they were serving as Montessori training providers for AMS at the time of the survey. Considering the size of AMS in the United States relative to AMI, this is not a surprising distribution. All participants had spent at least six years as Montessori classroom teachers, and half had been serving as trainers for more than 25 years. We did not ask for gender, race, or ethnicity in the survey because the vast majority of experienced teacher educators are White females, leaving little doubt that our sample reflected that demographic.

\section{Instrument}

The 32 identified participants received an email approved in our IRB protocol, which included a link to an anonymous online survey on the Qualtrics platform. The survey began with an information statement as stipulated by the IRB, required about 30 minutes to complete, and included no honorarium or incentive. Participants could withdraw at any time by choosing not to participate in the online study. Because the survey link was anonymous, no unique identifying information or personal data were collected.

The MCT-EL rubric itself is lengthy and detailed, so the survey was programmed so that each participant provided feedback on only a portion of the components. The rubric itself was broken down into three blocks, and the survey software randomly assigned one of these blocks to each participant. Before being shown the randomly selected component of the rubric, participants were presented with an overview image to give them a general understanding of the complete rubric. The stimuli presented to participants are provided in Appendix A. As a consequence of the random rotation of the stimuli, the number of reviewers for each block was not equal and varied from four to seven.

After each of the four images in the assigned block was presented to a participant, the participant was asked to rate three statements on a 7-point Likert scale, with responses that included strongly disagree, somewhat disagree, slightly disagree, neither agree nor disagree, slightly agree, somewhat agree, and strongly agree. The three statements were (a) "Consistent with Montessori pedagogy," (b) "Terminology is clear," and (c) "Reasonable progression of expectations for each practice." After the ratings, participants were prompted with an opportunity to provide open-ended comments: "Please explain your ratings above to help us improve the component of the rubric."

After participants completed the series of questions for each of the four elements they were randomly assigned to review, an image of the overall coaching rubric was provided, along with an opportunity for them to provide feedback on the entire framework. They were asked to use the same Likert scale to rate the degree to which the rubric covered the most important practices and the extent to which it would be useful for developing teachers. Four final, open-ended questions concluded the evaluation of the rubric, related to (a) an explanation of ratings, (b) the biggest strength of the rubric, (c) anything missing from the rubric, and (d) any final suggestions for improvement. Finally, the survey collected information about participants' professional background.

\section{Analysis Procedures}

Given the small sample size for this study, quantitative analysis was conducted in Microsoft Excel. The Likert items were analyzed descriptively in terms of the frequency of rating values assigned, which allowed us to gauge the relative strength and weakness of each subsection. This approach was recommended by Sullivan and Artino (2013) as the best way to analyze and interpret Likert-scale data.

Microsoft Excel was also employed in the analysis of the qualitative data, which allowed for the sorting of comments by topic and emerging themes. The qualitative data were examined using the process of thematic analysis as outlined by Braun and Clarke (2012). Specifically, we followed the process they described as "systematically identifying, organizing, and offering insight into patterns 
of meaning (themes) across a data set” (p. 57). They further clarified that the valuable patterns of meaning are those that are important relative to the specific research question at hand.

We chose to follow the integration approach for a convergent mixed-methods design described by Creswell and Plano Clark (2018), involving organization of the results by major topic. These topics were related to the study's research questions and allowed quantitative analysis for each topic to be followed by an analysis of qualitative responses for themes and opportunities to improve individual items.

\section{Results}

Presentation of results is organized around our three research questions and includes both quantitative and qualitative findings.

\section{Research Question 1: Is the rubric valuable?}

When asked to rate their agreement level regarding the rubric being useful for developing teachers, $75 \%$ of experts indicated they strongly agreed it would be valuable, $19 \%$ responded that they somewhat agreed, and $6 \%$ indicated they somewhat disagreed. Many experts were positive in their open-ended comments about the overall value of the rubric:

- "This is an outstanding rubric that will be useful to all Elementary Montessori programs! It provides concrete components of practice for coaching teachers."

- "Overall, I think this is an excellent rubric."

- "This is a tremendous undertaking that is very well done. The suggestions I have made today should in no way be taken to be a criticism of the work done to date! I offer them in the spirit of wanting to address the most common problems I see with new teachers in my work with the TEP. Please accept my thanks and admiration for this work!"

One participant felt the rubric had merit but needed more work: "I think that the overall components have validity, but the rubrics are not ready for implementation yet." Another participant summed up the challenge of creating a valuable rubric: "The truest success of the Elementary Montessori guide is when the children trust them and collaborate with them. How do we measure that?"
Reliability is an important consideration when evaluating the usefulness of a rubric. While we did not have pilot data to calculate interrater reliability of the rubric in use, we were able to ascertain a measure of reliability for participants' ratings of the rubric items. Consistency within these ratings gives us confidence that the reactions to the items reflected common understanding and criteria for assessing their usefulness. We calculated James et al.s (1984) interrater agreement (IRA) $r_{\text {wg }}$ for single items, indicating the proportion of variance caused by agreement according to the formula in Equation 1:

$$
r_{w g}=1-\left(S_{\mathrm{x}}^{2} / \sigma_{\mathrm{eu}}^{2}\right) \text {, }
$$

where we used the common practice of employing the uniform distribution to obtain $\sigma_{\text {eu }}^{2}$, where $A$ is the number of discrete Likert response alternatives. In this case, it was seven for a $\sigma_{\text {eu }}^{2}$ value of 4 , representing the variance of completely random responses (Mood et al., 1974), as shown in Equation 2:

$$
\sigma_{\text {eu }}^{2}=\left(A^{2}-1\right) / 12
$$

Across the 70 items, the range of $r_{w g}$ was .52 to 1.00 , with an average of 84 . In interpreting IRA, values of 1 represent complete agreement and values of 0 indicate completely random responses, so values closer to 1 reflect more substantial agreement. A common rule of thumb for interpreting $r_{w g}$ is based on a practical standard of a cutoff of .70 (O'Neill, 2017). With an average $r_{w g}$ of .84 and only seven of the 70 items evaluated in this small sample falling below this threshold, our results suggest reasonable agreement in ratings among our experts.

\section{Research Question 2: What are the rubric's strengths and weaknesses?}

\section{Strengths}

When asked what they believed was the biggest strength of this coaching rubric, participants commented on the structure, content, and potential impact of the rubric. Many of them viewed the structure of the rubric as a strength, indicating they appreciated the rubric's organization, simplicity, breadth, and developmental nature. In terms of structure, one commented on the organization: "The specificity of the criteria, as well as the structure of the rubric, where one could see what improvement would look like, is a real strength." Another comment identified a strength: "The thoughtful, professional, well-informed development of this rubric is a strength, and its ease of use and simplicity / objectivity 
of its language." Several comments addressed the breadth of the rubric, believing it was "comprehensive" and provided "specifics." Two comments highlighted feelings about the coverage of the rubric:

- "The rubric has clear and concise language and is progressive in the ratings. I feel you have covered the majority of areas that need to be considered in a coaching rubric."

- "The breadth of areas viewed gives ample opportunities for improvement but also for the teacher to see what [they are] doing well."

Other comments demonstrated that the developmental aspects of the structure were also appealing.

- "I like that it can be used to document change over time."

- "Clearly identifies components of the teacher's role and shows progressive steps for improvement with the rubric. It's a rubric for reflection."

- "I think a strength is that mentors can understand the student teaching is a developmental process, and expectations and guidance should recognize that. We need to look at Developing [one of the performance levels described in the rubric presented to participants] for goals in the initial weeks of a placement."

- "The specificity of the criteria, as well as the structure of the rubric, where one could see what improvement would look like, is a real strength."

- "Clarity of expectations and how to grow to next level."

- "The rubric has clear and concise language and is progressive in the ratings."

Participants also valued that the rubric was grounded in Montessori pedagogy and philosophy and was therefore appropriate for use in a Montessori Elementary classroom. Many comments reflected this perspective.

- "It covers the basics of what it means to implement Montessori philosophy and best practices for a novice teacher."

- "I think a strength is having a rubric founded on Montessori pedagogy and philosophy."

- "Components are logical, and this is a very good rubric of reference.”
- "The overall components included are valid points and touch important aspects of working with children in a Montessori setting."

- "It is thorough, comprehensive, and grounded in Montessori philosophy. It values what we [Montessori professionals] value."

Finally, the reviewers recognized a key strength in the potential impact of the rubric on early-career teachers:

- "The sections are well divided. The rubric has subcategories to support growth and development gradually."

- "[It helps] young and experienced teachers take stock and become more conscious."

- "It provides a (somewhat) objective rubric for measuring one's practice. I think that it could provide both the coach and the new teacher a fair experience."

\section{Weaknesses}

Although participants identified many strengths of the rubric, we were particularly interested in where they saw weaknesses. We will discuss specific items that participants identified that were missing from the rubric in the next section, but here we outline larger issues that they viewed as lacking. Several participants needed more information about how, specifically, to use the rubric:

- 'I don't see information on how the coach and the 'coachee' would be matched for their work. Is it purely a job performance experience, or more of a mentoring / relationship experience? In either case, the match-up and the reason for providing coaching would be critical. I realize that is all outside of this rubric, however."

- "[Need an] explanation of how it should be used, how often, who should be using it, a section for 'goals' to be established based on the rating given, and strategies for reaching the goals."

Questions and suggestions also emerged about next steps in the rubric's development and implementation:

- 'I am assuming that there is a 'minimum' that is suggested for field consultants. Will this be a digital rubric that allows [field consultants] to make additional notes to verify their rating?"

- "I hope you are piloting the rubric in a wide range 
of classrooms to include public, private, [classrooms that are] inclusive of special education students, and classrooms that are diverse."

- "When [the rubric] is implemented, there might be a suggestion for observers to assess only some areas on a particular visit and other areas on another visit.

- "I also think it might be really interesting to have the person being coached complete the matrix (selfassessment) so that the debrief can focus on those areas where the mentor and the mentee see things quite differently or on areas where both agree there is room for growth. This could be quite powerful!"

- "How do you expect a teacher to reach the expected goals toward perfection?"

\section{Research Question 3: What improvements are necessary for specific elements of the rubric?}

Participants evaluated components of the rubric in blocks, as described previously. For each block, they rated consistency with Montessori pedagogy, clarity of terminology, and reasonableness of the expectation progression. They also provided open-ended comments to elaborate on their ratings. The feedback on specific elements of the rubric is broken down between quantitative results and qualitative results.

\section{Ratings}

We summarized participants' ratings for various elements of the rubric in Figure 1. In terms of consistency with Montessori pedagogy, participants provided the highest proportion of ratings of 7 on the 7-point scale for the items related to Delivery (86\%) and Organization (71\%) of presentations, Observation (75\%), Redirection (71\%), and teacher Demeanor (75\%). The element about teacher Conduct received the fewest ratings of 7 on the 7-point scale for consistency with Montessori pedagogy (25\%). Terminology elements that received the highest number of ratings of 7 on the 7-point scale were Organization (86\%) and Delivery (86\%) of lessons with teacher Conduct close behind (75\%). Terminology for Choice and Independence received no ratings of 7 on the 7-point scale. The progression elements related to lesson Delivery (71\%) received the most 7 ratings on the 7-point scale. No other progression elements came close, and Choice and Independence both received no ratings of 7 on the 7-point scale.

\section{Qualitative Results}

Likert ratings, particularly for the Demeanor and Conduct elements, indicated that improvements were needed in progressions, along with clearer terminology. Examining participants' suggestions for refining the existing items provided insights into necessary refinements. The paragraphs that follow explore comments organized into the areas of consistency with Montessori pedagogy, clarity of terminology, and appropriateness of progressions. This section concludes with a discussion of recommended additional items for the rubric.

Consistency With Montessori Pedagogy. Although ratings for consistency with Montessori pedagogy were fairly positive, some participants made comments related to their professional experience and perspectives on Montessori philosophy.

- "New teachers sometimes think that the best lesson is the one that is rolled out verbatim from the album .... Rather than memorize lessons and deliver them AT the children like a prerecorded message, we encourage them to tell THEIR story based on the version of the story in the album ...."

- "I placed less emphasis on analyzed movements and limited language than did my Primary trainer colleagues .... The Elementary Montessori teacher has to appeal to the older child's imagination. Our stories do still need to be limited-we sow the seeds, we present the keys, we're not just entertaining them-but they must not be dry or too brief.'

One participant identified a specific point of disagreement:

- "Overall, it works with one striking point of disagreement-Classroom Leadership issue. Teaching with your back to the wall is one extreme, the other being giving your whole self to the child to encourage currents of mental energy with full focus on the child and his lesson. The assistant can keep things calm. Scanning all the time is not modeling concentration."

Clarity of Terminology. A significant amount of feedback revolved around clarifying terminology: 
Figure 1

Relative Ratings for Each Rubric Component

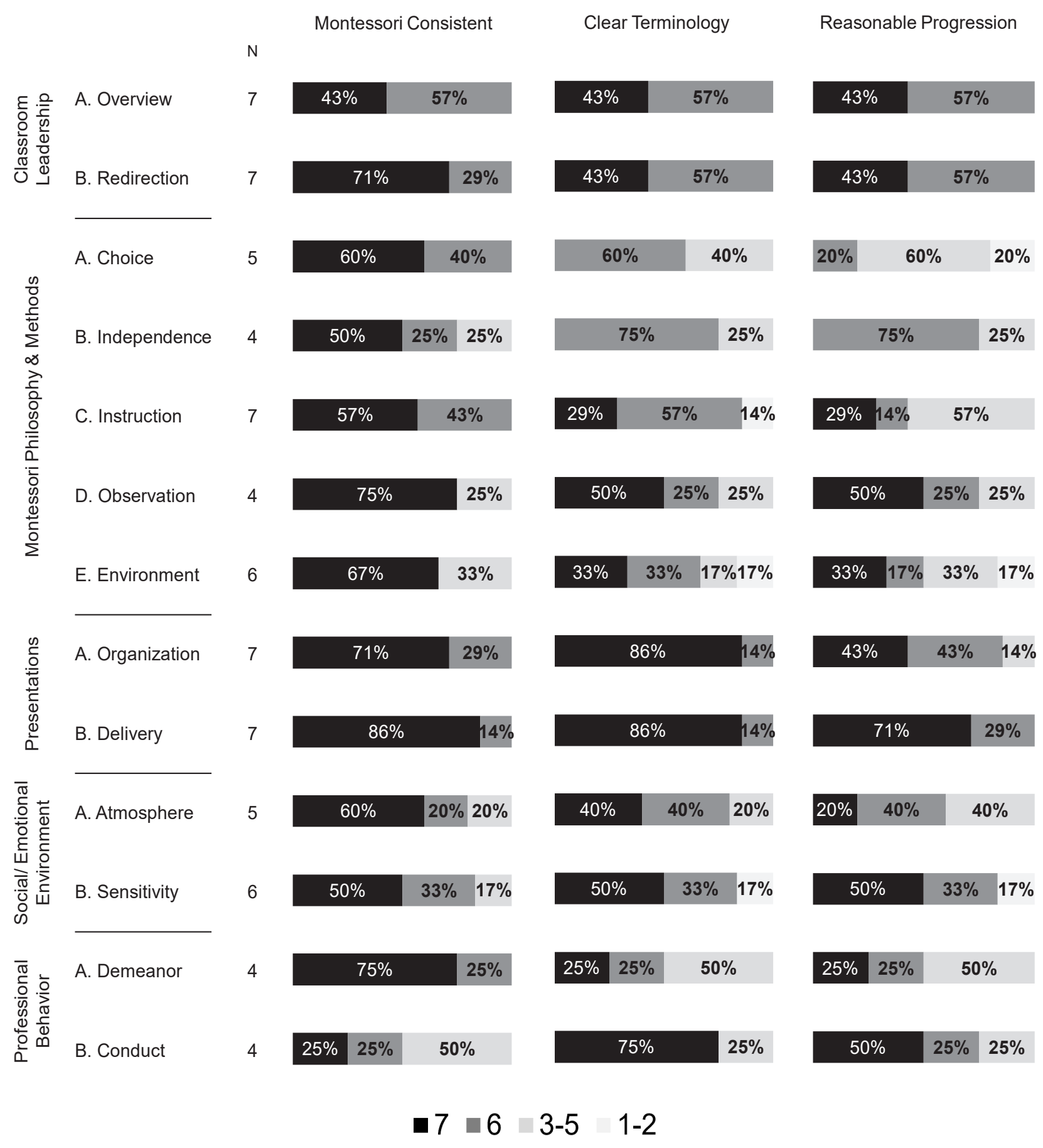

Note. The range of the 7-Point Likert scale was strongly disagree (1), somewhat disagree (2), slightly disagree (3), neither agree nor disagree (4), slightly agree (5), somewhat agree (6), and strongly agree (7). 
- "Under Classroom Leadership—is there another word that you can use for 'Redirection'? Redirection has a negative connotation. What about using 'Guidance'?"

- 'I do not use the terms 'on-task' or 'off-task' in my Montessori work. The work of the children is self-construction. How can they be 'off-task' then? The lessons, activities, materials, experiences are all invitations to inspire and structure and guide that self-construction. But in my experience, what gets deemed 'off-task' is often a child manifesting some other aspect of the self-constructive work."

- "The only thing I 'bumped on' here was the word 'reinforced,' which sounds a bit harsh-I prefer 'upheld' or 'supported' (Integrating / item 1)."

- “'Permits,' 'Allows,' and similar language make the adult the keeper of knowledge; in Montessori, we know the children learn through their own actions."

Appropriateness of Progressions. The largest number of comments related to specific concerns with the rubric's progressions. Many participants identified particular items where progressions did not seem to be continual scales:

- "I think that the scales do not show accurate 'progressions' of skill in implementation.... They don't reflect a true progression."

- "Like all rubrics, there are a few places where it would be tricky to use simply because the 5 descriptions within a given element are neither mutually exclusive nor cumulative."

- "These rubrics don't always base their progression on the same points of observation, introducing a variety of goals that are sometimes like comparing apples and oranges."

- "The progression from Developing to Maturing to Integrating does not seem consistent-there appear to be different criteria introduced at each of those levels rather than deepening or expanding the criteria from the previous levels."

- "I feel that some of the explanations for categories above are arbitrarily assigned a space in the linear scale."

Other concerns related to the number of points that the items used:
- "I am feeling that maybe you are trying to get too many categories on the rating scale."

- "A rubric with so many components can be very useful with less of a progression (three instead of five) since you are covering so many areas."

Finally, some participants noted that the language in the progressions had a negative tone as mentioned in these quotes:

- “The first level, 'unaware,' seems very negative."

- "Rework all of the rubrics to be less negative (for the first column)."

- "Consider language that puts children at the center rather than the adult: 'helps children maintain journals; children understand reasons why this is important.",

- "Phrase positives, e.g., able to be objective rather than inferring in observation: The girl cries rather than the girl is sad."

Suggestions for Additions. Although 94\% of participants agreed either strongly (50\%) or somewhat (44\%) that the MCT-EL rubric covers the most important practices, they also provided valuable suggestions for additions for the rubric. Qualitative feedback mentioned the importance of addressing practices related to diversity, equity, and inclusion in the rubric.

- "One of the biggest challenges for new and experienced Montessori teachers is differentiating instruction for students with learning differences and disabilities and collaborating with special education faculty. Inclusivity is a major focus in education today."

- "I'd suggest inclusion of something referencing the teacher's sensitivity to their school's culture and community - and responsiveness to equity, diversity, and inclusion goals."

Given today's challenges with the COVID-19 pandemic, one participant pointed out the importance of self-care for teachers: "I wonder if there should be an element under Professionalism to address self-care. Montessorians are really bad at self-care in a normal year; the pandemic ... has exacerbated this issue." Finally, another participant suggested including the relationship with a classroom 
assistant through "directing/guiding" as an important leadership skill to be developed. Other suggestions for potential topics to be added to the rubric included curriculum planning, technology, reflective practice, assisting children, assessment, and sections for each subject area.

\section{Discussion}

Overall, the results from these experts suggest that the MCT-EL rubric is comprehensive and valuable. They especially appreciated its objectivity and the design that clearly articulates professional progression. Participants rated the rubric as highly consistent with Montessori pedagogy, but opportunities for improvement exist in the clarity of the terminology and some aspects of the progressions in performance-quality level. Specifically, participants rated consistency with Montessori pedagogy more favorably than clarity of terminology and reasonableness of the progressions. Participants were similarly positive about the rubric covering the most important Elementary practices but suggested additions did emerge from the qualitative analysis, particularly in the area of diversity, equity, and inclusion. Qualitative data also supported the quantitative results that found opportunities for improvement in terminology and the progression descriptions of performance-quality level. In fact, the largest number of comments related to the progressions across levels of performance quality; many were related to the possibility that some language was negative in tone or some of the scales did not seem to truly be a continuum. Qualitative results related to terminology largely revolved around concerns with specific words (e.g., "redirect," "off-task," "reinforced," and "permits") that seemed inconsistent with Montessori philosophy.

When we examined the results across dimensions, the most positive ratings were evident in the four elements comprising the Classroom Leadership and Presentations components of the rubric (i.e., Overview, Redirection, Organization, and Delivery). Almost all respondents reviewing these dimensions indicated they either strongly or somewhat agreed that the criteria and indicators provided were consistent with Montessori pedagogy, they used clear terminology, and they listed a reasonable progression. No disagreement or neutrality was expressed for these dimensions. These elements also generated few comments in the qualitative data. The ratings for Instruction, Observation, and Environment in the Montessori Philosophy and Methods dimension fell in the middle of all elements - with more ratings of slightly agree, disagree, or neither agree nor disagreealthough no ratings reflected a level of strong or moderate degree of disagreement. These results were similar to those for Atmosphere and Conduct, although Conduct had the lowest ratings for being aligned with Montessori pedagogy. The elements with the least positive ratings were Choice, Demeanor, Independence, and Sensitivity.

\section{Limitations}

While this study generated a great deal of valuable insight into refining the MCT-EL rubric, a number of limitations existed. First, the study included a small sample size, and the number of ratings for each component of the rubric was even smaller, to make the task manageable for participants. We also acknowledge that the sample had very little diversity, which is unfortunately consistent with the population of Montessori teacher trainers. Finally, as this study focused on the content of the rubric components with a very small sample, we did not address reliability issues. To remedy these problems, we intend to conduct future research to examine the MCT-EL rubric through a diversity, equity, and inclusion lens and to pilot the revised rubric with a larger sample of preservice and early-career teachers to allow more-sophisticated quantitative analysis.

\section{Future Directions: Revisions for the MCT-EL Rubric}

The results of this study led to revisions of the MCTEL rubric to enhance its usability in the field. This section outlines how we incorporated the results from this study into a revised version of the rubric. We first organized the data by strength and frequency to better understand consistent themes and the areas in most need of revision. Modifications were made, one element at a time, by systematically addressing each practice individually. After carefully reviewing the extensive feedback from the expert Montessori teacher educators, we revised the rubric. Continuing our iterative process, we asked a small group of experienced Montessori teacher educators to informally review the changes we made, which resulted in additional revisions we incorporated into a new version of the MCT-EL rubric, provided in Appendix B. A number of areas were revised according to specific suggestions for how items could be changed, while others required refinement according to general feedback. Examples 
of how these changes were reflected in revisions to the elements and dimensions, specific practices, and indicators are discussed in the paragraphs that follow.

To ensure that no section was overwhelmingly large and unwieldy and to enhance the intuitive logic of the framework, the first modification was a reorganization of the elements. We divided the Montessori Philosophy and Methods dimension into two subsections: Montessori Philosophy (with the Choice, Independence, and Observation elements), and Montessori Methods (with the Instruction and Environment elements). In addition, three element titles were changed. Under Classroom Leadership, we changed Overview to Awareness and Redirection to Guidance. Within Professional Behavior, we changed Conduct to Development and redistributed practices to align better with the change in the title. Additional changes were made in both the practices themselves and the indicators of progression levels.

Practices

The number of practices was expanded from 70 to 81 to incorporate areas that were deemed lacking; additions included:

- Collaborates with the classroom assistant (for lead teachers).

- Integrates technology.

- Provides educational differentiation.

- Supports quiet and active pursuits.

- Fosters home and school partnerships.

- Addresses implicit bias.

- Supports social justice goals.

- Practices self-care.

- Connects with each child.

Additional changes were made for clarity and consistency with Montessori theory:

- Wording added or changed (e.g., "Lessons are wellprepared" became "Prepares lessons in advance").

- Structure altered so each statement begins with a verb (providing consistency across practices); for example, "Materials appropriately placed" becomes "Places materials appropriately."

One item, Implements Routines, was removed because all the indicators for this practice should be exhibited by a beginning teacher.
Indicators

Many of the indicators in the individual progressions were edited for clarity, accuracy, and completeness, as suggested by participants. The most significant changes were made in the progression of indicators from Beginning to Maturing. Our goal was to ensure the Beginning column listed all basic indicators, the Developing column represented somewhat morecomplex skills, and the Maturing column included practices that were even more advanced. In addition, indicators originally listed in the Integrating column were combined with the practices they described, and all indicators in the Unaware column were reworded in positive terms.

Although the feedback from participants was extensive, we recognize that the relatively small number of participants is a limitation for any statistical analysis. However, the rich qualitative data provided sufficient insight for development of major improvements to the rubric. Out of respect for participants' time, we asked each person to provide detailed feedback on only about one-third of the complete rubric. We believe this was necessary to ensure that the task was manageable and that participants did not abandon the online survey before completion; however, this segmented presentation of the complete rubric limited participants' ability to envision how the fully implemented rubric might function in practice. We hope to address these limitations by continuing to collect feedback as early-career teachers and their mentors use the rubric in real classrooms in the field.

\section{Conclusion and Future Directions}

Extensive background research provided the foundation for the development of the MCT-EL rubric that was presented to Montessori teacher-education experts. These participants provided thorough, thoughtful, and detailed feedback on the value of the rubric and specific opportunities for refinement. We meticulously incorporated this valuable input into a revised version of the rubric, which is provided in Appendix B. A downloadable version of the MCT-EL rubric is available in the Supplementary Materials for this article. In conducting this research study, we learned a great deal, not only about the goals we set out to achieve, but also about how to design a process for rigorously examining the validity of this type of coaching rubric. Our approach and the acknowledgments of its limitations can serve as lessons for 
future researchers as interest in designing instruments and rubrics grows in the field of Montessori education.

The revised MCT-EL rubric has the potential to contribute to the field of Montessori education by enhancing the development of early-career educators as they grow in their proficiency with Montessori pedagogy. The rubric provides a solid foundation for additional coaching and mentoring tools to facilitate the development of highly qualified teachers. Our hope is that teacher educators and school administrators will find opportunities to explore this rubric with early-career teachers as they refine their craft. If readers apply the rubric in their work, we encourage them to contact us to describe their experiences.

\section{Author Information}

Angela K. Murray is an assistant research professor at the University of Kansas, director of the KU Center for Montessori Research in the Achievement and Assessment Institute, and editor of the Journal of Montessori Research. http://orcid.org/0000-0001-6310-8842

Carolyn J. Daoust is a research associate at the KU Center for Montessori Research in the Achievement and Assessment Institute. She can be reached at cjdaoust@ku.edu.

https://orcid.org/0000-0002-4853-4496

Jan Mallett is a research assistant professor at Southern Methodist University. https://orcid.org/0000-0002-7755-1252

\section{References}

Allen, S., \& Knight, J. (2009). A method for collaboratively developing and validating a rubric (EJ1136714). ERIC. International Journal for the Scholarship of Teaching and Learning, 3(2), Article 10. https://files.eric.ed.gov/fulltext/EJ1136714.pdf Alsina, A., Ayllón, S., Colomer, J., Fernández-Peña, R., Fullana, J., Pallisera, M., Pérez-Burriel, M., \& Serra, L. (2017). Improving and evaluating reflective narratives: A rubric for higher education students. Teaching and Teacher Education, 63, 148-158. https://doi.org/10.1016/j.tate.2016.12.015 American Educational Research Association [AERA], American Psychological Association, \& National
Council on Measurement in Education. (2014). Standards for educational and psychological testing. AERA Publications.

American Montessori Society. (2018). AMS accreditation standards. https://amshq.org/Educators/ Montessori-Schools/AMS-Accreditation/ Accreditation-Standards

Association Montessori Internationale. (2017-2018). Annette Haines: Spokesperson for Montessori values, scholarship, and research. The NAMTA Journal, 43(1-2).

Association Montessori Internationale. (2009). AMI/ USA Montessori school standards. Association Montessori Internationale / USA.

Association Montessori Internationale Canada. (n.d.). AMI Elementary classes: Detailed description. https:// www.ami-canada.com/guidelineselementary.html

Baker, K., Hicks, C., Pottish-Lewis, P., \& Travis, A. S. (2008). Cosmic education: A collection of talks given by AMI elementary trainers at the 2008 Cosmic Education Workshop. Association Montessori Internationale / USA.

Bartolome, S. J. (2017). Comparing field-teaching experiences: A longitudinal examination of preservice and first-year teacher perspectives. Journal of Research in Music Education, 65(3), 264-286. https://www.jstor.org/stable/48588621

Braun, V., \& Clarke, V. (2012). Thematic analysis. In H. Cooper, P. M. Camic, D. L. Long, A. T. Panter, D. Rindskopf, \& K. J. Sher (Eds.), APA handbook of research methods in psychology, Vol. 2. Research designs: Quantitative, qualitative, neuropsychological, and biological (pp. 57-71). American Psychological Association.

Braun, V., Clarke, V., Boulton, E., Davey, L., \& McEvoy, C. (2020). The online survey as a qualitative research tool. International Journal of Social Research Methodology. https://doi.org/10.1080/13645579.2020.1805550

Brookhart, S. M. (2013). How to create and use rubrics for formative assessment and grading. ASCD.

Canzoneri-Golden, L., \& King, J. (2020). An examination of culturally relevant pedagogy and antibias antiracist curriculum in a Montessori setting. [Doctoral dissertation, Lynn University]. SPIRAL. https://spiral.lynn.edu/etds/360

Chattin-McNichols, J. (1992). The Montessori controversy. Delmar Publishers. 
Creswell, J. W., \& Plano Clark, V. L. (2017). Designing and conducting mixed methods research (3rd ed.). SAGE Publications.

Culclasure, B. T., Daoust, C. J., Cote, S. M., \& Zoll, S. (2019). Designing a logic model to inform Montessori research. Journal of Montessori Research, 5(1), 35-49. https://doi.org/10.17161/ jomr.v5i1.9788

Damore, S., \& Rieckhoff, B. (2021). Leading reflective practices in Montessori schools. Journal of Montessori Research, 7(1), 51-65. https://journals.ku.edu/jmr/ article/view/14832

Daoust, C., \& Suzuki, S. (2013, March 13-17). Montessori magnets and charters: Similarities and differences in implementation. [Poster presentation]. Annual conference of the American Montessori Society, Orlando, FL, United States.

Daoust, C., \& Suzuki, S. (2014, March 26-30). Public Montessori elementary: Three models of implementation. [Poster presentation]. Annual conference of the American Montessori Society, Dallas, TX, United States.

Edwards, C. P., Hamel, E., Miller, J. L., \& Ren, L. (2020). Improving reflective practice: A documentation rubric for mentoring preservice and in-service teachers. Journal of early Childhood Teacher Education, 41(1), 2-17. https://doi.org/10.1080/10901027.20 $\underline{18.1463321}$

Elish-Piper, L., \& L'Allier, S. (2011). Examining the relationship between literacy coaching and student reading gains in grades $\mathrm{K}-3$. The Elementary School Journal, 112(1), 83-106. https://doi. org $/ 10.1086 / 660685$

Epstein, P. (2012). An observer's notebook: Learning from children with the observation C.O.R.E. Montessori Foundation Press.

Feldon, D. F. (2007). The implications of research on expertise for curriculum and pedagogy. Educational Psychology Review, 19(2), 91-110. https://doi. org/10.1007/s10648-006-9009-0

Furze, J., Gale, J. R., Black, L., Cochran, T. M., \& Jensen, G. M. (2015). Clinical reasoning: Development of a grading rubric for student assessment. Journal of Physical Therapy Education, 29(3), 34-45. https:// journals.lww.com/jopte/Fulltext/2015/29030/ Clinical_Reasoning _ Development_of a Grading.6.aspx

Linstone, H. A., \& Turoff, M. (Eds.). (1975). The Delphi method: Techniques and applications. Addison-Wesley.
Grazzini, B. K. (2010). The role of the disciplines for cosmic education. Communications 2010 Special Issue, 84-93. https://montessoricongress2017.org/ images/image/Speaker/BAIBA\%20KRUMINS\%20 GRAZZINI/The\%20Role\%20of\%20the\%20 Disciplines\%20for\%20Cosmic\%20Education.pdf

Gulikers, J., Brinkman, D., \& Runhaar, P. (2021). Using a rubric to grasp intercultural competence development in vocational education. Journal of Vocational Education \& Training, 73(1), 47-70, https://doi.org/10.1080/13636820.2019.1688854

Huneke Stone, E. (2019). What we've learned, and what we're learning. Montessori Public, (3) 3, 7. https://www.montessoripublic.org/wp-content/ uploads/2019/05/MP Articles-PDF V33-HunekeStone.pdf

James, L. R., Demaree, R. G., \& Wolf, G. (1984). Estimating within group interrater reliability with and without response bias. Journal of Applied Psychology, 69(1), 85-98. https://doi. org/10.1037/0021-9010.69.1.85

Kahn, D. (Ed.). (1995). What is Montessori elementary? North American Montessori Teachers' Association.

Kraft, M. A., \& Blazar, D. (2017). Individualized coaching to improve teacher practice across grades and subjects: New experimental evidence. Educational Policy, 31(7), 1033-1068. https://doi. org/10.1177/0895904816631099

Kraft, M. A., Blazar, D., \& Hogan, D. (2018). The effect of teacher coaching on instruction and achievement: A meta-analysis of the causal evidence. Review of Educational Research, 88(4), 547-588. https://doi. org/10.3102/0034654318759268

Lillard, A., \& McHugh, V. (2019a). Authentic Montessori: The environment: The Dottoressa's view at the end of her life Part I. Journal of Montessori Research, 5(1), 1-18. https://doi.org/10.17161/ jomr.v5i1.7716

Lillard, A., \& McHugh, V. (2019b). Authentic Montessori: The teacher and the child: The Dottoressa's view at the end of her life Part II. Journal of Montessori Research, 5(1), 19-34. https://doi. org/10.17161/jomr.v5i1.9753

Lillard, A. S. (2017). Montessori: The science behind the genius. Oxford University Press.

Lillard, P. P. (1996). Montessori today. Schocken.

MacDonald, G. (2016). Becoming a scientific observer (EJ1125300). ERIC. The NAMTA Journal, (41)3, 
132-171. https://files.eric.ed.gov/fulltext/ EJ1125300.pdf

Miller, K. A., Collada, B., Tolliver, D., Audi, Z., Cohen, A., Michelson, C., \& Newman, L. R. (2020). Using the modified Delphi method to develop a tool to assess pediatric residents supervising on inpatient rounds. Academic Pediatrics, 20(1), 89-96. https:// doi.org/10.1016/j.acap.2019.07.012

Montessori Australia Foundation. (2012). Montessori National Curriculum, November 2011. The NAMTA Journal, 37(1).

Montessori, M. (1963). Education for a new world. Kalakshetra.

Montessori, M. (1964). The Montessori Method (A. E. George, Trans.). Schocken Books. (Original work published 1912)

Montessori, M. (1965). The advanced Montessori Method: Scientific pedagogy as applied to the education of children from seven to eleven years, Vol. I, Spontaneous activity in education. Kalakshetra.

Montessori, M. (1966). The secret of childhood. Fides Publishers.

Montessori, M. (1970). The child in the family. Avon.

Montessori, M. (1971). Four planes of education: Text of a lecture given during the Montessori congress in 1938 in Edinburgh and of another given in London in March 1939. American Montessori Internationale.

Montessori, M. (1972). Education and peace (H. R. Lane, Trans.). Henry Regnery. (Original work published 1949)

Montessori, M. (1973). To educate the human potential (5th ed.). Kalakshetra.

Montessori, M. (1976). From childhood to adolescence. Schocken.

Montessori, M. (1988). The discovery of the child. Clio Press. (Original work published 1948)

Montessori, M. (1989). The absorbent mind. Dell Publishing. (Original work published 1949)

Montessori, M. (2008). The child, society, and the world: Unpublished speeches and writings. MontessoriPierson.

Montessori, M. (1997a). Basic ideas of Montessori's educational theory: Extracts from Maria Montessori's writings and teachings. Clio Press.

Montessori, M. (1997b). The California lectures of Maria Montessori, 1915: Unpublished speeches and writings. Clio Press.

Montessori, M. M., Jr. (1976). Education for human development. Schocken.
Mood, A. M., Graybill, F. A., \& Boes, D. C.

(1974). Introduction to the theory of statistics. McGraw-Hill.

Murray, A., Daoust, C., \& Chen, J. (2019). Developing instruments to measure Montessori instructional practices. Journal of Montessori Research, 5(1), 50-87. https://doi.org/10.17161/jomr.v5i1.9797

National Center for Montessori in the Public Sector. (2019). Montessori assessment playbook. Author.

National Center for Montessori in the Public Sector. (2021). Support for new schools and programs adding levels or expanding their scope. https://www. public-montessori.org/services/\#support

North America Montessori Teachers' Association. (2013). Montessori voices: Guided by nature: The house of children. The NAMTA Journal, 38(1), 11-19.

O’Neill, T. A. (2017). An overview of interrater agreement on Likert scales for researchers and practitioners. Frontiers in Psychology, 8(777). https:// doi.org/10.3389/fpsyg.2017.00777

Panadero, E., \& Jonsson, A. (2020). A critical review of the arguments against the use of rubrics. Educational Research Review, 30. https://doi.org/10.1016/j. edurev.2020.100329

Pendersen, H., \& Pendersen, J. A. (2008). What is Montessori? A basic guide to the principles, practices, and benefits of a Montessori education. Sandpiper Press.

Pottish-Lewis, P. (2011). Elementary classroom management: How to implement cosmic education. AMI/USA.

Public Montessori in Action. (n.d.). Professional development. https://montessori-action.org/ professional-development

Qualtrics. (n.d.). How to increase online survey response rates. https://www.qualtrics.com/experiencemanagement/research/tools-increase-response-rate/

Rambusch, N. M., \& Stoops, J. A. (1992). The authentic American Montessori school: A guide to the self-study, evaluation, and accreditation of American schools committed to Montessori education. American Montessori Society, the Middle States Association of Colleges and Schools, and the Commission on Elementary Schools.

Saylor, L. L., McKenzie, G., \& Sacco, C. C. (2018). Teacher-centered mentorship as meaningful professional development. Journal of Montessori Research, 4(2), 10-32. https://doi.org/10.17161/ jomr.v4i2.6923 
Slade, E. G. (2021). Montessori in action: Building resilient Montessori schools. Wiley.

Standing, E. M. (1984). Maria Montessori: Her life and work. New American Library. (Original work published 1957)

Sullivan, G. M., \& Artino, A. R., Jr (2013). Analyzing and interpreting data from Likert-type scales. Journal of Graduate Medical Education, 5(4), 541-542. https:// doi.org/10.4300/JGME-5-4-18

Tchekmedyian, V., Shields, H. M., Pelletier, S. R., \& Pazo, V. C. (2017). The effect of rubric-guided, focused, personalized coaching sessions and video-recorded presentations on teaching skills among fourthyear medical students: A pilot study. Journal of the Association of American Medical Colleges, 92(11), 1583-1589. https://doi.org/10.1097/ $\underline{\text { ACM. } 0000000000001686}$

Timmerman, B. E. C., Strickland, D. C., Johnson, R. L., \& Payne, J. R. (2011). Development of a 'universal' rubric for assessing undergraduates' scientific reasoning skills using scientific writing. Assessment \& Evaluation in Higher Education, 36 (5), 509547.https://doi.org/10.1080/02602930903540991
Van Ginkel, S., Laurentzen, R., Mulder, M., Mononen, A., Kyttä, J., \& Kortelainen, M. J. (2017). Assessing oral presentation performance: Designing a rubric and testing its validity with an expert group. Journal of Applied Research in Higher Education, 9(3), 474-486. https://doi.org/10.1108/JARHE-02-2016-0012

Vernon-Feagans, L., Kainz, K., Hedrik, A., Ginsburg, M., \& Amendum, S. (2013). Live webcam coaching to help early elementary classroom teachers provide effective literacy instruction for struggling readers: The Targeted Reading Intervention. Journal of Educational Psychology, 105(4), 1175-187.https:// doi.org/10.1037/a0032143

Wyld, J. (2019). Making some changes in teacher training. Montessori Public, (3)3, 1-2. https:// www.montessoripublic.org/wp-content/ uploads/2019/05/MP_Articles-PDF_V33-Wyld. pdf

Zugelder, B. S., L'Esperance, M., Conetta, P. J., \& Watts, T. (2019). Use of edTPA rubric constructs in teacher induction. In L. Barron, (Ed.), A practical guide for edTPA implementation: Lessons from the field (pp. 415-434). Information Age Publishing. 


\section{Appendix A: Survey Stimuli}

First, participants were presented with an overview image to provide a general understanding of the complete rubric. For the questions participants responded to, the survey software randomly chose which of the three alternative blocks was presented to any given participant. Each of the blocks contained four individual images. This appendix includes the overview image as well as the three possible blocks presented. Instructions from the survey read:

The Montessori Coaching Tool Elementary (MCT-EL) rubric is a detailed rubric that contains specific items representing five components of Montessori Elementary practice. Out of respect for your time, we will not be asking you to provide feedback on the entire rubric. Instead, we are asking different people to review different sections assigned randomly. To provide context, this image illustrates all five components covered in the rubric. On the next series of screens you will be asked to respond to questions related to specific items within a subset of the five components.

\section{Overview Presented to All Participants}

\section{Montessori Elementary Teacher Coaching Tool}

\section{Teacher Performance Rubric Overview}

\section{Components of Practice Considered}

\begin{tabular}{|c|c|c|c|c|}
\hline $\begin{array}{l}\text { Classroom } \\
\text { Leadership } \\
\text { - Overview } \\
\text { - Redirection }\end{array}$ & $\begin{array}{l}\text { Montessori } \\
\text { Philosophy/ } \\
\text { Methods } \\
\text { - Choice } \\
\text { - Independence } \\
\text { - Instruction } \\
\text { - Observation } \\
\text { - Environment }\end{array}$ & $\begin{array}{l}\text { Presentations } \\
\text { - Organization } \\
\text { - Delivery }\end{array}$ & $\begin{array}{l}\text { The Social/ } \\
\text { Emotional } \\
\text { Environment } \\
\text { - Atmosphere } \\
\text { - Sensitivity }\end{array}$ & $\begin{array}{l}\text { Professional } \\
\text { Behavior } \\
\text { - Demeanor } \\
\text { - Conduct }\end{array}$ \\
\hline
\end{tabular}




\section{Alternative Block 1 (four images)}

\begin{tabular}{|c|c|c|c|c|c|}
\hline \multicolumn{6}{|c|}{ I. Classroom Leadership } \\
\hline A. Overview & Unaware & Beginning & Developing & Maturing & Integrating \\
\hline $\begin{array}{l}\text { 1. Positions } \\
\text { with back to } \\
\text { a wall }\end{array}$ & $\begin{array}{l}\text { Does not } \\
\text { position with } \\
\text { his/ her back to } \\
\text { a wall. }\end{array}$ & $\begin{array}{l}\text { Usually avoids } \\
\text { facing a wall or } \\
\text { shelf during } \\
\text { lessons. }\end{array}$ & $\begin{array}{l}\text { Back is toward } \\
\text { a wall while } \\
\text { observing and } \\
\text { during most } \\
\text { lessons. }\end{array}$ & $\begin{array}{l}\text { Consistently } \\
\text { positions with } \\
\text { back to a wall, } \\
\text { near room } \\
\text { edges. }\end{array}$ & $\begin{array}{l}\text { Positions for } \\
\text { maximum } \\
\text { overview during } \\
\text { lessons and } \\
\text { otherwise. }\end{array}$ \\
\hline $\begin{array}{l}\text { 2. Scans the } \\
\text { room }\end{array}$ & $\begin{array}{l}\text { Does not look } \\
\text { around the } \\
\text { classroom. }\end{array}$ & $\begin{array}{l}\text { Occasionally } \\
\text { scans the room. }\end{array}$ & $\begin{array}{l}\text { More } \\
\text { consistently } \\
\text { looks up and } \\
\text { around during } \\
\text { lessons. }\end{array}$ & $\begin{array}{l}\text { Incorporates } \\
\text { room scans into } \\
\text { and between } \\
\text { lessons. }\end{array}$ & $\begin{array}{l}\text { Scans often to } \\
\text { maintain } \\
\text { awareness of } \\
\text { the classroom. }\end{array}$ \\
\hline 3. Listens & $\begin{array}{l}\text { Does not seem } \\
\text { aware of } \\
\text { sounds in the } \\
\text { environment. }\end{array}$ & $\begin{array}{l}\text { Occasionally } \\
\text { turns toward a } \\
\text { loud sound. }\end{array}$ & $\begin{array}{l}\text { More } \\
\text { consistently } \\
\text { turns toward } \\
\text { unusual } \\
\text { sounds. }\end{array}$ & $\begin{array}{l}\text { Reacts to } \\
\text { sounds } \\
\text { suggesting off- } \\
\text { task behavior. }\end{array}$ & $\begin{array}{l}\text { Listens to } \\
\text { monitor activity } \\
\text { in the } \\
\text { classroom. }\end{array}$ \\
\hline $\begin{array}{l}\text { 4. Balances } \\
\text { adults in the } \\
\text { room }\end{array}$ & $\begin{array}{l}\text { Does not } \\
\text { spatially } \\
\text { balance other } \\
\text { adults in the } \\
\text { classroom. }\end{array}$ & $\begin{array}{l}\text { Is becoming } \\
\text { aware when } \\
\text { other adults are } \\
\text { teaching or } \\
\text { have left the } \\
\text { room. }\end{array}$ & $\begin{array}{l}\text { Begins to } \\
\text { position away } \\
\text { from other } \\
\text { adults. }\end{array}$ & $\begin{array}{l}\text { Repositions to } \\
\text { balance other } \\
\text { adults, checks } \\
\text { in with them } \\
\text { verbally or non- } \\
\text { verbally. }\end{array}$ & $\begin{array}{l}\text { Works as a } \\
\text { team with other } \\
\text { adults to } \\
\text { maximize } \\
\text { overview. }\end{array}$ \\
\hline $\begin{array}{l}\text { 5. Prioritizes } \\
\text { assistance }\end{array}$ & $\begin{array}{l}\text { Does not } \\
\text { prioritize when } \\
\text { assisting } \\
\text { children. }\end{array}$ & $\begin{array}{l}\text { Notices } \\
\text { assistance is } \\
\text { needed by } \\
\text { nearby children } \\
\text { and } \\
\text { approaches. }\end{array}$ & $\begin{array}{l}\text { Monitors } \\
\text { children within } \\
15 \text { feet; moves } \\
\text { from one group } \\
\text { to the next. }\end{array}$ & $\begin{array}{l}\text { Begins to scan } \\
\text { the room before } \\
\text { determining } \\
\text { where to } \\
\text { approach. }\end{array}$ & $\begin{array}{l}\text { Assistance is } \\
\text { based on whole } \\
\text { class } \\
\text { awareness. }\end{array}$ \\
\hline $\begin{array}{l}\text { 6. Manages } \\
\text { whole group } \\
\text { activities }\end{array}$ & $\begin{array}{l}\text { Does not } \\
\text { successfully } \\
\text { lead whole } \\
\text { group activities. }\end{array}$ & $\begin{array}{l}\text { Maintains the } \\
\text { group's } \\
\text { attention briefly } \\
\text { while reading a } \\
\text { story, singing, } \\
\text { etc. }\end{array}$ & $\begin{array}{l}\text { Attains attention } \\
\text { prior to a group } \\
\text { activity and can } \\
\text { hold attention } \\
\text { for } 10 \text { min. }\end{array}$ & $\begin{array}{l}\text { Leads the } \\
\text { whole group for } \\
15 \text { min. } \\
\text { regaining } \\
\text { attention as } \\
\text { needed. }\end{array}$ & $\begin{array}{l}\text { Appropriately } \\
\text { selected whole } \\
\text { group activities } \\
\text { are well run, } \\
\text { short and } \\
\text { enjoyable. }\end{array}$ \\
\hline
\end{tabular}




\begin{tabular}{|c|c|c|c|c|c|}
\hline \multicolumn{6}{|c|}{ I. Classroom Leadership } \\
\hline B. Redirection & Unaware & Beginning & Developing & Maturing & Integrating \\
\hline $\begin{array}{l}\text { 1. Implements } \\
\text { rules and } \\
\text { procedures }\end{array}$ & $\begin{array}{l}\text { Does not } \\
\text { implement } \\
\text { rules and } \\
\text { procedures. }\end{array}$ & $\begin{array}{l}\text { Begins to } \\
\text { convey and } \\
\text { reinforce } \\
\text { classroom rules } \\
\text { and procedures. }\end{array}$ & $\begin{array}{l}\text { More reliably } \\
\text { responds to rule } \\
\text { and procedure } \\
\text { noncompliance. }\end{array}$ & $\begin{array}{l}\text { Consistently } \\
\text { addresses rule } \\
\text { and procedure } \\
\text { noncompliance. }\end{array}$ & $\begin{array}{l}\text { Rules and } \\
\text { procedures are } \\
\text { clearly } \\
\text { communicated } \\
\text { and reinforced. }\end{array}$ \\
\hline $\begin{array}{l}\text { 2. Enables } \\
\text { self- } \\
\text { correction }\end{array}$ & $\begin{array}{l}\text { Does not } \\
\text { enable children } \\
\text { to self-correct } \\
\text { behavior. }\end{array}$ & $\begin{array}{l}\text { States what to } \\
\text { do and avoids } \\
\text { negative } \\
\text { directives e.g. } \\
\text { "walk" instead } \\
\text { of "don't run". }\end{array}$ & $\begin{array}{l}\text { Begins to } \\
\text { redirect } \\
\text { nonverbally and } \\
\text { with questions } \\
\text { while avoiding } \\
\text { "you need to". }\end{array}$ & $\begin{array}{l}\text { Does not nag, } \\
\text { and points } \\
\text { things out in a } \\
\text { matter of fact } \\
\text { way, e.g. "I } \\
\text { notice...". }\end{array}$ & $\begin{array}{l}\text { Avoids power } \\
\text { struggles by } \\
\text { emphasizing } \\
\text { prompts and } \\
\text { problem } \\
\text { solving. }\end{array}$ \\
\hline $\begin{array}{l}\text { 3. Is non- } \\
\text { judgmental }\end{array}$ & $\begin{array}{l}\text { Does not use } \\
\text { factual } \\
\text { information to } \\
\text { draw } \\
\text { conclusions. }\end{array}$ & $\begin{array}{l}\text { Begins to avoid } \\
\text { snap judgments } \\
\text { of behavior. }\end{array}$ & $\begin{array}{l}\text { More } \\
\text { consistently } \\
\text { avoids } \\
\text { assumptions } \\
\text { and } \\
\text { preconceived } \\
\text { notions. }\end{array}$ & $\begin{array}{l}\text { Obtains } \\
\text { information } \\
\text { before drawing } \\
\text { conclusions and } \\
\text { responding. }\end{array}$ & $\begin{array}{l}\text { Understands } \\
\text { children who } \\
\text { misbehave } \\
\text { have needs that } \\
\text { are not being } \\
\text { met. }\end{array}$ \\
\hline $\begin{array}{l}\text { 4. Monitors } \\
\text { redirection }\end{array}$ & $\begin{array}{l}\text { Does not } \\
\text { monitor } \\
\text { redirection. }\end{array}$ & $\begin{array}{l}\text { Is starting to } \\
\text { observe a } \\
\text { child's response } \\
\text { after redirection. }\end{array}$ & $\begin{array}{l}\text { More } \\
\text { consistently } \\
\text { notices if } \\
\text { redirection has } \\
\text { been effective. }\end{array}$ & $\begin{array}{l}\text { Usually } \\
\text { monitors re- } \\
\text { direction } \\
\text { encouraging } \\
\text { compliance } \\
\text { when needed. }\end{array}$ & $\begin{array}{l}\text { Dependably } \\
\text { and } \\
\text { productively } \\
\text { monitors } \\
\text { redirection. }\end{array}$ \\
\hline
\end{tabular}

\begin{tabular}{|l|l|l|l|l|l|}
\hline \multicolumn{1}{|l|}{ III. Presentations } \\
\hline $\begin{array}{l}\text { A. Organization } \\
\text { lessons }\end{array}$ & $\begin{array}{l}\text { Unaware } \\
\text { 1. Appropriate } \\
\text { choose } \\
\text { appropriate } \\
\text { lessons for } \\
\text { children. }\end{array}$ & $\begin{array}{l}\text { Beginning } \\
\text { ages to guide } \\
\text { lesson } \\
\text { selection. }\end{array}$ & $\begin{array}{l}\text { Developing } \\
\text { lessons based } \\
\text { on observed } \\
\text { interest. }\end{array}$ & $\begin{array}{l}\text { Mses } \\
\text { observation, } \\
\text { record keeping } \\
\text { and discussions } \\
\text { to select } \\
\text { interesting } \\
\text { lessons. }\end{array}$ & $\begin{array}{l}\text { Lessons are } \\
\text { appropriate for } \\
\text { children's ages, } \\
\text { interest, } \\
\text { experience and } \\
\text { ability. }\end{array}$ \\
$\begin{array}{l}\text { 2. Lessons are } \\
\text { well-prepared }\end{array}$ & $\begin{array}{l}\text { Does not } \\
\text { prepare } \\
\text { lessons ahead } \\
\text { of time. }\end{array}$ & $\begin{array}{l}\text { Albums are } \\
\text { consulted and } \\
\text { notes taken } \\
\text { prior to giving } \\
\text { lessons. }\end{array}$ & $\begin{array}{l}\text { Refers to notes } \\
\text { briefly and } \\
\text { unobtrusively } \\
\text { during lessons. }\end{array}$ & $\begin{array}{l}\text { Lessons usually } \\
\text { flow and are } \\
\text { consistent with } \\
\text { album } \\
\text { descriptions. }\end{array}$ & $\begin{array}{l}\text { Lessons flow, } \\
\text { and are clear, } \\
\text { complete and } \\
\text { concise. }\end{array}$ \\
$\begin{array}{l}\text { 3. Needed } \\
\text { materials } \\
\text { available }\end{array}$ & $\begin{array}{l}\text { Does not } \\
\text { gather } \\
\text { required } \\
\text { materials prior } \\
\text { to lessons. }\end{array}$ & $\begin{array}{l}\text { Most materials } \\
\text { needed are on } \\
\text { hand when } \\
\text { lessons begin. }\end{array}$ & $\begin{array}{l}\text { Materials } \\
\text { remain } \\
\text { available to } \\
\text { children after } \\
\text { lessons. }\end{array}$ & $\begin{array}{l}\text { Appropriate } \\
\text { follow up } \\
\text { materials are } \\
\text { made available. }\end{array}$ & $\begin{array}{l}\text { All materials } \\
\text { needed are } \\
\text { available during } \\
\text { and following } \\
\text { lessons. }\end{array}$ \\
\hline $\begin{array}{l}\text { 4. Materials } \\
\text { appropriately } \\
\text { placed }\end{array}$ & $\begin{array}{l}\text { Does not } \\
\text { place } \\
\text { materials } \\
\text { appropriately } \\
\text { during } \\
\text { lessons. }\end{array}$ & $\begin{array}{l}\text { Materials are } \\
\text { orderly placed } \\
\text { during most } \\
\text { lessons. }\end{array}$ & $\begin{array}{l}\text { Materials are } \\
\text { placed directly } \\
\text { in front of } \\
\text { children during } \\
\text { most lessons. }\end{array}$ & $\begin{array}{l}\text { Material } \\
\text { placements are } \\
\text { consistent with } \\
\text { album } \\
\text { descriptions. }\end{array}$ & $\begin{array}{l}\text { Materials are } \\
\text { placed } \\
\text { accurately and } \\
\text { in easy reach of } \\
\text { children during } \\
\text { each lesson. }\end{array}$ \\
\hline
\end{tabular}




\begin{tabular}{|c|c|c|c|c|c|}
\hline \multicolumn{6}{|c|}{ III. Presentations } \\
\hline B. Delivery & Unaware & Beginning & Developing & Maturing & Integrating \\
\hline $\begin{array}{l}\text { 1. Uses } \\
\text { accurate, } \\
\text { limited } \\
\text { language }\end{array}$ & $\begin{array}{l}\text { Does not use } \\
\text { accurate, } \\
\text { limited } \\
\text { language. }\end{array}$ & $\begin{array}{l}\text { Begins to use } \\
\text { accurate } \\
\text { language during } \\
\text { lessons. }\end{array}$ & $\begin{array}{l}\text { Precise } \\
\text { language is } \\
\text { used with few } \\
\text { embellishments. }\end{array}$ & $\begin{array}{l}\text { Adapts } \\
\text { language to } \\
\text { children's } \\
\text { responses. }\end{array}$ & $\begin{array}{l}\text { Language flows, } \\
\text { and is clear, } \\
\text { accurate, } \\
\text { appropriately } \\
\text { adjusted, and } \\
\text { limited. }\end{array}$ \\
\hline $\begin{array}{l}\text { 2. Uses } \\
\text { accurate, } \\
\text { precise } \\
\text { movements }\end{array}$ & $\begin{array}{l}\text { Does not use } \\
\text { accurate, } \\
\text { precise } \\
\text { movements. }\end{array}$ & $\begin{array}{l}\text { Begins to move } \\
\text { materials slowly } \\
\text { and accurately } \\
\text { during lessons. }\end{array}$ & $\begin{array}{l}\text { Uses clear, } \\
\text { exact } \\
\text { movements } \\
\text { without } \\
\text { bouncing the } \\
\text { hand. }\end{array}$ & $\begin{array}{l}\text { Carefully and } \\
\text { accurately } \\
\text { manipulates } \\
\text { materials during } \\
\text { most lessons. }\end{array}$ & $\begin{array}{l}\text { Materials are } \\
\text { precisely and } \\
\text { correctly } \\
\text { manipulated } \\
\text { throughout each } \\
\text { lesson. }\end{array}$ \\
\hline $\begin{array}{l}\text { 3. Lessons are } \\
\text { interactive }\end{array}$ & \begin{tabular}{|l} 
Does not give \\
interactive \\
lessons.
\end{tabular} & $\begin{array}{l}\text { Involves } \\
\text { children at } \\
\text { some point } \\
\text { during lessons. }\end{array}$ & $\begin{array}{l}\text { Involves } \\
\text { children early } \\
\text { on during } \\
\text { lessons. }\end{array}$ & $\begin{array}{l}\text { Engages each } \\
\text { child often in } \\
\text { each lesson. }\end{array}$ & $\begin{array}{l}\text { Engages children } \\
\text { in highly } \\
\text { interactive } \\
\text { lessons. }\end{array}$ \\
\hline $\begin{array}{l}\text { 4. Lessons } \\
\text { stay on } \\
\text { topic }\end{array}$ & $\begin{array}{l}\text { Does not give } \\
\text { short, focused } \\
\text { lessons. }\end{array}$ & $\begin{array}{l}\text { Refocuses } \\
\text { lessons that } \\
\text { have veered off } \\
\text { course. }\end{array}$ & $\begin{array}{l}\text { Remains on } \\
\text { topic during } \\
\text { most lessons. }\end{array}$ & $\begin{array}{l}\text { The majority of } \\
\text { lessons are } 15 \\
\text { minutes or less. }\end{array}$ & $\begin{array}{l}\text { Lessons stay on } \\
\text { topic and are } \\
\text { short in duration. }\end{array}$ \\
\hline $\begin{array}{l}\text { 5. Modifies } \\
\text { lesson } \\
\text { pacing }\end{array}$ & $\begin{array}{l}\text { Does not modify } \\
\text { lesson pacing } \\
\text { based on } \\
\text { children's } \\
\text { responses. }\end{array}$ & $\begin{array}{l}\text { Begins to notice } \\
\text { when a lesson's } \\
\text { pace is too fast } \\
\text { or slow. }\end{array}$ & $\begin{array}{l}\text { Modifies a } \\
\text { lessons pace } \\
\text { according to } \\
\text { children's } \\
\text { responses. }\end{array}$ & $\begin{array}{l}\text { Reviews prior } \\
\text { learning and } \\
\text { gives a prior or } \\
\text { subsequent } \\
\text { lesson if } \\
\text { needed. }\end{array}$ & $\begin{array}{l}\text { Gives well-paced } \\
\text { lessons that aren't } \\
\text { too hard or too } \\
\text { easy. }\end{array}$ \\
\hline $\begin{array}{l}\text { 6. Connects } \\
\text { with } \\
\text { children }\end{array}$ & $\begin{array}{l}\text { Does not } \\
\text { connect with } \\
\text { children during } \\
\text { lessons. }\end{array}$ & $\begin{array}{l}\text { Begins to use } \\
\text { facial } \\
\text { expressions to } \\
\text { connect with } \\
\text { children. }\end{array}$ & $\begin{array}{l}\text { Acknowledges } \\
\text { children's } \\
\text { reactions during } \\
\text { most lessons. }\end{array}$ & $\begin{array}{l}\text { Responds to } \\
\text { children with } \\
\text { warmth and } \\
\text { empathy. }\end{array}$ & $\begin{array}{l}\text { Maintains a } \\
\text { connection with } \\
\text { each child } \\
\text { throughout each } \\
\text { lesson. }\end{array}$ \\
\hline $\begin{array}{l}\text { 7. Checks for } \\
\text { under- } \\
\text { standing }\end{array}$ & $\begin{array}{l}\text { Does not check } \\
\text { for } \\
\text { understanding } \\
\text { during lessons. }\end{array}$ & $\begin{array}{l}\text { Observes } \\
\text { children's } \\
\text { material use } \\
\text { during lessons. }\end{array}$ & $\begin{array}{l}\text { Observes } \\
\text { during and after } \\
\text { lessons to } \\
\text { assess ability to } \\
\text { use materials. }\end{array}$ & $\begin{array}{l}\text { Uses } 3 \text { period } \\
\text { lessons and } \\
\text { questions to } \\
\text { determine } \\
\text { understanding. }\end{array}$ & $\begin{array}{l}\text { Integrates } \\
\text { observation, } 3 \\
\text { period lessons } \\
\text { and questions to } \\
\text { assess } \\
\text { understanding. }\end{array}$ \\
\hline $\begin{array}{l}\text { 8. Supports } \\
\text { struggling } \\
\text { children }\end{array}$ & $\begin{array}{l}\text { Does not } \\
\text { support } \\
\text { struggling } \\
\text { children. }\end{array}$ & $\begin{array}{l}\text { Recognizes } \\
\text { when children } \\
\text { are struggling } \\
\text { with an activity. }\end{array}$ & $\begin{array}{l}\text { Notices and } \\
\text { begins to } \\
\text { assess why } \\
\text { children have } \\
\text { difficulty with an } \\
\text { activity. }\end{array}$ & $\begin{array}{l}\text { Tries different } \\
\text { strategies to } \\
\text { help children } \\
\text { challenged by } \\
\text { an activity. }\end{array}$ & $\begin{array}{l}\text { Implements } \\
\text { appropriate } \\
\text { solutions when } \\
\text { children struggle } \\
\text { with an activity. }\end{array}$ \\
\hline $\begin{array}{l}\text { 9. Offers } \\
\text { follow-up } \\
\text { suggestions }\end{array}$ & $\begin{array}{l}\text { Does not offer } \\
\text { follow-up } \\
\text { suggestions. }\end{array}$ & \begin{tabular}{|l|} 
Avoids \\
assigning \\
follow-up \\
activities.
\end{tabular} & $\begin{array}{l}\text { Begins to } \\
\text { provide suitable } \\
\text { ideas for follow- } \\
\text { up activities. }\end{array}$ & $\begin{array}{l}\text { Provides follow- } \\
\text { up how-to } \\
\text { instruction when } \\
\text { needed. }\end{array}$ & $\begin{array}{l}\text { Offers appealing } \\
\text { follow-up } \\
\text { suggestions } \\
\text { aligned with } \\
\text { children's } \\
\text { interests and } \\
\text { ability. }\end{array}$ \\
\hline
\end{tabular}


Alternative Block 2 (five images)

\begin{tabular}{|c|c|c|c|c|c|}
\hline \multicolumn{6}{|c|}{ II. Montessori Philosophy/Methods } \\
\hline A. Choice & Unaware & Beginning & Developing & Maturing & Integrating \\
\hline $\begin{array}{l}\text { 1. Facilitates } \\
\text { choice with } \\
\text { lessons }\end{array}$ & $\begin{array}{l}\text { Does not } \\
\text { facilitate activity } \\
\text { choice by giving } \\
\text { lessons. }\end{array}$ & $\begin{array}{l}\text { Invites } \\
\text { participation in } \\
\text { lessons and } \\
\text { avoids telling } \\
\text { children what } \\
\text { work to do. }\end{array}$ & $\begin{array}{l}\text { Refrains from } \\
\text { assigning work } \\
\text { discussing work } \\
\text { options instead. }\end{array}$ & $\begin{array}{l}\text { Introduces } \\
\text { interesting } \\
\text { activities to } \\
\text { encourage self- } \\
\text { selection. }\end{array}$ & $\begin{array}{l}\text { Gives many } \\
\text { well-timed } \\
\text { lessons } \\
\text { facilitating } \\
\text { choice and } \\
\text { concentrated } \\
\text { activity. }\end{array}$ \\
\hline $\begin{array}{l}\text { 2. Promotes } \\
\text { co-activity }\end{array}$ & $\begin{array}{l}\text { Does not } \\
\text { promote co- } \\
\text { activity. }\end{array}$ & $\begin{array}{l}\text { Permits children } \\
\text { to work together } \\
\text { and instruct one } \\
\text { another. }\end{array}$ & $\begin{array}{l}\text { Allows children } \\
\text { to choose with } \\
\text { whom they } \\
\text { work. }\end{array}$ & $\begin{array}{l}\text { Structures } \\
\text { activities so } \\
\text { children work } \\
\text { together } \\
\text { successfully. }\end{array}$ & $\begin{array}{l}\text { Facilitates } \\
\text { productive } \\
\text { coactivity, } \\
\text { collaboration } \\
\text { and peer } \\
\text { instruction. }\end{array}$ \\
\hline $\begin{array}{l}\text { 3. Supports } \\
\text { productive } \\
\text { work choice }\end{array}$ & $\begin{array}{l}\text { Does not help } \\
\text { children choose } \\
\text { appropriate } \\
\text { activities. }\end{array}$ & $\begin{array}{l}\text { Is becoming } \\
\text { aware of } \\
\text { children unable } \\
\text { to choose } \\
\text { activities. }\end{array}$ & $\begin{array}{l}\text { Alternately } \\
\text { selects work } \\
\text { and offers } \\
\text { choice for a } \\
\text { child unable to } \\
\text { choose. }\end{array}$ & $\begin{array}{l}\text { Avoids inhibiting } \\
\text { choice with } \\
\text { praise, rewards, } \\
\text { deadlines, etc. }\end{array}$ & $\begin{array}{l}\text { Develops the } \\
\text { choice making } \\
\text { ability of each } \\
\text { child. }\end{array}$ \\
\hline $\begin{array}{l}\text { 4. Fosters } \\
\text { choice } \\
\text { through } \\
\text { procedures }\end{array}$ & $\begin{array}{l}\text { Does not enact } \\
\text { procedures } \\
\text { supporting } \\
\text { children's } \\
\text { choice making. }\end{array}$ & $\begin{array}{l}\text { Involves } \\
\text { children in } \\
\text { making } \\
\text { classroom } \\
\text { rules. }\end{array}$ & $\begin{array}{l}\text { Children decide } \\
\text { where to sit, } \\
\text { how long to use } \\
\text { an activity, and } \\
\text { when to have } \\
\text { snack. }\end{array}$ & $\begin{array}{l}\text { Facilitates } \\
\text { choice with a 3- } \\
\text { hr uninterrupted } \\
\text { work period. }\end{array}$ & $\begin{array}{l}\text { Enacts } \\
\text { procedures that } \\
\text { provide } \\
\text { decision- } \\
\text { making } \\
\text { opportunities. }\end{array}$ \\
\hline $\begin{array}{l}\text { 5. Promotes } \\
\text { choice with } \\
\text { material } \\
\text { availability }\end{array}$ & $\begin{array}{l}\text { Does not } \\
\text { provide children } \\
\text { with a full range } \\
\text { of elementary } \\
\text { Montessori } \\
\text { materials. }\end{array}$ & $\begin{array}{l}\text { Makes age- } \\
\text { appropriate } \\
\text { manipulative } \\
\text { materials } \\
\text { available. }\end{array}$ & $\begin{array}{l}\text { Makes timelines } \\
\text { and charts } \\
\text { available. }\end{array}$ & $\begin{array}{l}\text { Makes } \\
\text { experiment and } \\
\text { large timeline } \\
\text { making } \\
\text { materials } \\
\text { available. }\end{array}$ & $\begin{array}{l}\text { Supports } \\
\text { productive } \\
\text { choice with a } \\
\text { full range of } \\
\text { elementary } \\
\text { Montessori } \\
\text { materials. }\end{array}$ \\
\hline
\end{tabular}




\begin{tabular}{|c|c|c|c|c|c|}
\hline \multicolumn{6}{|c|}{ II. Montessori Philosophy/Methods } \\
\hline B. Independence & Unaware & Beginning & Developing & Maturing & Integrating \\
\hline $\begin{array}{l}\text { 1. Emphasizes } \\
\text { careful } \\
\text { handling of } \\
\text { materials }\end{array}$ & $\begin{array}{l}\text { Does not } \\
\text { emphasize } \\
\text { careful } \\
\text { handling of } \\
\text { materials. }\end{array}$ & $\begin{array}{l}\text { Begins to notice } \\
\text { when materials } \\
\text { aren't used, } \\
\text { carried or } \\
\text { returned } \\
\text { properly. }\end{array}$ & $\begin{array}{l}\text { Models } \\
\text { appropriate } \\
\text { handling of } \\
\text { materials. }\end{array}$ & $\begin{array}{l}\text { Reviews the } \\
\text { proper handling } \\
\text { of materials } \\
\text { when needed. }\end{array}$ & $\begin{array}{l}\text { Supports } \\
\text { careful material } \\
\text { retrieval, use } \\
\text { and } \\
\text { replacement. }\end{array}$ \\
\hline $\begin{array}{l}\text { 2. Respects } \\
\text { student work } \\
\text { spaces }\end{array}$ & $\begin{array}{l}\text { Does not } \\
\text { respect } \\
\text { children's work } \\
\text { areas. }\end{array}$ & $\begin{array}{l}\text { Avoids touching } \\
\text { children's work } \\
\text { without } \\
\text { permission. }\end{array}$ & $\begin{array}{l}\text { Helps children } \\
\text { straighten a dis- } \\
\text { organized } \\
\text { workspace. }\end{array}$ & $\begin{array}{l}\text { Introduces } \\
\text { methods for } \\
\text { maintaining an } \\
\text { organized } \\
\text { workspace. }\end{array}$ & $\begin{array}{l}\text { Respects each } \\
\text { child's work } \\
\text { space. }\end{array}$ \\
\hline $\begin{array}{l}\text { 3. Supports self- } \\
\text { reliance }\end{array}$ & $\begin{array}{l}\text { Does not } \\
\text { support } \\
\text { children's self- } \\
\text { reliance. }\end{array}$ & $\begin{array}{l}\text { Avoids } \\
\text { completing } \\
\text { children's } \\
\text { activities or } \\
\text { stating what to } \\
\text { do. }\end{array}$ & $\begin{array}{l}\text { Asks problem } \\
\text { solving } \\
\text { questions when } \\
\text { children face } \\
\text { difficulties. }\end{array}$ & $\begin{array}{l}\text { Monitors activity } \\
\text { discreetly, } \\
\text { assists briefly } \\
\text { and checks } \\
\text { back in as } \\
\text { needed. }\end{array}$ & $\begin{array}{l}\text { Recognizes } \\
\text { when children } \\
\text { need help or } \\
\text { can do activities } \\
\text { themselves. }\end{array}$ \\
\hline $\begin{array}{l}\text { 4. Facilitates } \\
\text { productive } \\
\text { use of time }\end{array}$ & $\begin{array}{l}\text { Does not } \\
\text { facilitate } \\
\text { productive use } \\
\text { of time. }\end{array}$ & $\begin{array}{l}\text { Helps children } \\
\text { maintain work } \\
\text { journals and } \\
\text { explains } \\
\text { reasons for } \\
\text { doing so. }\end{array}$ & $\begin{array}{l}\text { Meets regularly } \\
1 \text {-on-1 with } \\
\text { children to } \\
\text { review journals } \\
\text { and plan } \\
\text { activities. }\end{array}$ & $\begin{array}{l}\text { Monitors } \\
\text { agreed-on goals } \\
\text { and mutually } \\
\text { creates } \\
\text { solutions when } \\
\text { plans fall short. }\end{array}$ & $\begin{array}{l}\text { Monitors and } \\
\text { supports each } \\
\text { child's work } \\
\text { goals and } \\
\text { effective use of } \\
\text { time. }\end{array}$ \\
\hline $\begin{array}{l}\text { 5. Clarifies work } \\
\text { expectations }\end{array}$ & $\begin{array}{l}\text { Does not } \\
\text { clarify work } \\
\text { expectations. }\end{array}$ & $\begin{array}{l}\text { Begins to define } \\
\text { freedoms } \\
\text { offered and } \\
\text { work } \\
\text { responsibilities. }\end{array}$ & $\begin{array}{l}\text { Provides } \\
\text { children with } \\
\text { access to public } \\
\text { school } \\
\text { requirements. }\end{array}$ & $\begin{array}{l}\text { Establishes and } \\
\text { clearly } \\
\text { communicates } \\
\text { classroom work } \\
\text { expectations. }\end{array}$ & $\begin{array}{l}\text { Helps each } \\
\text { child balance } \\
\text { freedom and } \\
\text { responsibility in } \\
\text { the classroom. }\end{array}$ \\
\hline $\begin{array}{l}\text { 6. Monitors } \\
\text { activity } \\
\text { outside of } \\
\text { lessons }\end{array}$ & $\begin{array}{l}\text { Does not } \\
\text { monitor } \\
\text { learning } \\
\text { outside of } \\
\text { lessons. }\end{array}$ & $\begin{array}{l}\text { Begins to } \\
\text { distinguish } \\
\text { between useful } \\
\text { and } \\
\text { unproductive } \\
\text { activity. }\end{array}$ & $\begin{array}{l}\text { Begins to find } \\
\text { the reasons } \\
\text { behind } \\
\text { unproductive } \\
\text { activity. }\end{array}$ & $\begin{array}{l}\text { Confers with } \\
\text { children to } \\
\text { refocus } \\
\text { unproductive } \\
\text { activity. }\end{array}$ & $\begin{array}{l}\text { Implements } \\
\text { agreed upon } \\
\text { solutions to help } \\
\text { prevent } \\
\text { unproductive } \\
\text { activity. }\end{array}$ \\
\hline
\end{tabular}




\begin{tabular}{|c|c|c|c|c|c|}
\hline \multicolumn{6}{|c|}{ II. Montessori Philosophy/Methods } \\
\hline D. Observation & Unaware & Beginning & Developing & Maturing & Integrating \\
\hline $\begin{array}{l}\text { 1. Records } \\
\text { observations }\end{array}$ & $\begin{array}{l}\text { Does not } \\
\text { observe and } \\
\text { record } \\
\text { observations. }\end{array}$ & $\begin{array}{l}\text { Records } \\
\text { observations } \\
\text { several times a } \\
\text { week. }\end{array}$ & $\begin{array}{l}\text { Records } \\
\text { observations } \\
\text { everyday. }\end{array}$ & $\begin{array}{l}\text { Regularly uses } \\
\text { a record } \\
\text { keeping system. }\end{array}$ & $\begin{array}{l}\text { Records } \\
\text { observations } \\
\text { daily and uses } \\
\text { an efficient } \\
\text { record keeping } \\
\text { system. }\end{array}$ \\
\hline $\begin{array}{l}\text { 2. Utilizes } \\
\text { recorded } \\
\text { observations }\end{array}$ & $\begin{array}{l}\text { Does not refer } \\
\text { to recorded } \\
\text { observations. }\end{array}$ & $\begin{array}{l}\text { Begins to } \\
\text { review notes for } \\
\text { lesson planning } \\
\text { purposes. }\end{array}$ & $\begin{array}{l}\text { Uses notes to } \\
\text { plan lessons } \\
\text { and adjust the } \\
\text { environment. }\end{array}$ & $\begin{array}{l}\text { Uses recorded } \\
\text { observations to } \\
\text { create student } \\
\text { reports. }\end{array}$ & $\begin{array}{l}\text { Uses } \\
\text { observation to } \\
\text { plan lessons, } \\
\text { modify the } \\
\text { classroom, and } \\
\text { generate } \\
\text { reports. }\end{array}$ \\
\hline $\begin{array}{l}\text { 3. Observes } \\
\text { objectively }\end{array}$ & $\begin{array}{l}\text { Does not } \\
\text { describe } \\
\text { children's } \\
\text { behavior } \\
\text { objectively. }\end{array}$ & $\begin{array}{l}\text { Begins to } \\
\text { describe } \\
\text { behavior } \\
\text { factually, e.g. } \\
\text { The boy throws } \\
\text { the hat. }\end{array}$ & $\begin{array}{l}\text { Avoids } \\
\text { evaluation, e.g. } \\
\text { The girl is rude. }\end{array}$ & $\begin{array}{l}\text { Avoids } \\
\text { attributing } \\
\text { cause or } \\
\text { inferring, e.g. } \\
\text { The girl cries, } \\
\text { not The girl is } \\
\text { sad. }\end{array}$ & $\begin{array}{l}\text { Avoids reaction } \\
\text { based on past } \\
\text { experiences, } \\
\text { beliefs, opinion } \\
\text { and/or biases. }\end{array}$ \\
\hline $\begin{array}{l}\text { 4. Records } \\
\text { objectively }\end{array}$ & $\begin{array}{l}\text { Does not } \\
\text { record } \\
\text { student's } \\
\text { activities } \\
\text { objectively. }\end{array}$ & $\begin{array}{l}\text { While note } \\
\text { taking avoids } \\
\text { labels and } \\
\text { absolutes, e.g. } \\
\text { never, always, } \\
\text { every. }\end{array}$ & $\begin{array}{l}\text { Can record } \\
\text { what is said and } \\
\text { done in a play- } \\
\text { by-play manner. }\end{array}$ & $\begin{array}{l}\text { Begins to } \\
\text { recognize } \\
\text { behavior } \\
\text { patterns in } \\
\text { notes. }\end{array}$ & $\begin{array}{l}\text { Records } \\
\text { impartially and } \\
\text { draws factually } \\
\text { based } \\
\text { conclusions. }\end{array}$ \\
\hline
\end{tabular}

\begin{tabular}{|c|c|c|c|c|c|}
\hline \multicolumn{6}{|c|}{ V. Professional Behavior } \\
\hline A. Demeanor & Unaware & Beginning & Developing & Maturing & Integrating \\
\hline $\begin{array}{l}\text { 1. Appropriate } \\
\text { dress }\end{array}$ & $\begin{array}{l}\text { Does not dress } \\
\text { appropriately. }\end{array}$ & $\begin{array}{l}\text { Avoids low } \\
\text { necklines, flip } \\
\text { flops, displaying } \\
\text { the mid-drift, } \\
\text { etc. }\end{array}$ & $\begin{array}{l}\text { Clothing is neat } \\
\text { and in good } \\
\text { repair. }\end{array}$ & $\begin{array}{l}\text { Accessories are } \\
\text { limited and } \\
\text { appropriate; } \\
\text { effort is made to } \\
\text { look attractive. }\end{array}$ & $\begin{array}{l}\text { Appearance is } \\
\text { appealing and } \\
\text { professional. }\end{array}$ \\
\hline $\begin{array}{l}\text { 2. Positive } \\
\text { attitude }\end{array}$ & $\begin{array}{l}\text { Does not } \\
\text { project a } \\
\text { positive attitude. }\end{array}$ & $\begin{array}{l}\text { Limits frowning } \\
\text { and negative } \\
\text { facial } \\
\text { expressions. }\end{array}$ & $\begin{array}{l}\text { Maintains a } \\
\text { relaxed posture; } \\
\text { seems to be } \\
\text { having fun. }\end{array}$ & $\begin{array}{l}\text { Is pleasant to } \\
\text { be around, and } \\
\text { facial } \\
\text { expression and } \\
\text { stance are } \\
\text { welcoming. }\end{array}$ & $\begin{array}{l}\text { Smiles often, is } \\
\text { warm, and } \\
\text { maintains a } \\
\text { positive, relaxed } \\
\text { attitude. }\end{array}$ \\
\hline $\begin{array}{l}\text { 3. Professional } \\
\text { commitment }\end{array}$ & $\begin{array}{l}\text { Does not } \\
\text { demonstrate } \\
\text { professional } \\
\text { commitment. }\end{array}$ & $\begin{array}{l}\text { Is eager to give } \\
\text { lessons and } \\
\text { assist children. }\end{array}$ & $\begin{array}{l}\text { Willingly } \\
\text { assumes } \\
\text { increased } \\
\text { classroom } \\
\text { responsibility. }\end{array}$ & $\begin{array}{l}\text { Participates in } \\
\text { whole school } \\
\text { activities. }\end{array}$ & $\begin{array}{l}\text { Is a committed } \\
\text { member of the } \\
\text { school } \\
\text { community. }\end{array}$ \\
\hline $\begin{array}{l}\text { 4. Wants to } \\
\text { improve } \\
\text { profession- } \\
\text { ally }\end{array}$ & $\begin{array}{l}\text { Does not show } \\
\text { openness to } \\
\text { improving } \\
\text { professionally. }\end{array}$ & $\begin{array}{l}\text { Avoids } \\
\text { defensiveness. }\end{array}$ & $\begin{array}{l}\text { Responds } \\
\text { favorably to } \\
\text { constructive } \\
\text { suggestions. }\end{array}$ & $\begin{array}{l}\text { Seeks advice } \\
\text { and help when } \\
\text { needed. }\end{array}$ & $\begin{array}{l}\text { Wants to } \\
\text { improve and do } \\
\text { his/her best } \\
\text { professionally. }\end{array}$ \\
\hline
\end{tabular}




\begin{tabular}{|c|c|c|c|c|c|}
\hline \multicolumn{6}{|c|}{ V. Professional Behavior } \\
\hline B. Conduct & Unaware & Beginning & Developing & Maturing & Integrating \\
\hline $\begin{array}{l}\text { 1. Moves } \\
\text { calmly }\end{array}$ & $\begin{array}{l}\text { Does not move } \\
\text { calmly through } \\
\text { the classroom. }\end{array}$ & $\begin{array}{l}\text { Usually } \\
\text { minimizes quick } \\
\text { movements in } \\
\text { the classroom. }\end{array}$ & $\begin{array}{l}\text { Movement is } \\
\text { unhurried and } \\
\text { limited. }\end{array}$ & $\begin{array}{l}\text { Approaches } \\
\text { children quietly } \\
\text { and } \\
\text { unperturbed. }\end{array}$ & $\begin{array}{l}\text { Moves calmly } \\
\text { with purpose } \\
\text { and composure. }\end{array}$ \\
\hline $\begin{array}{l}\text { 2. Listens } \\
\text { carefully }\end{array}$ & $\begin{array}{l}\text { Does not listen } \\
\text { attentively to } \\
\text { children. }\end{array}$ & $\begin{array}{l}\text { Communicates } \\
\text { with children at } \\
\text { eye level. }\end{array}$ & $\begin{array}{l}\text { Looks at children } \\
\text { while listening } \\
\text { with interest. }\end{array}$ & $\begin{array}{l}\text { Listens to } \\
\text { children with } \\
\text { undivided } \\
\text { attention. }\end{array}$ & $\begin{array}{l}\text { Talks with } \\
\text { children at eye } \\
\text { level and listens } \\
\text { attentively. }\end{array}$ \\
\hline $\begin{array}{l}\text { 3. Touches } \\
\text { respectfully }\end{array}$ & $\begin{array}{l}\text { Does not touch } \\
\text { children } \\
\text { respectfully. }\end{array}$ & $\begin{array}{l}\text { Refrains from } \\
\text { touching } \\
\text { children } \\
\text { excessively or } \\
\text { giving } \\
\text { unsolicited } \\
\text { hugs. }\end{array}$ & $\begin{array}{l}\text { Avoids pulling } \\
\text { children; offers a } \\
\text { hand if } \\
\text { appropriate. }\end{array}$ & $\begin{array}{l}\text { Touches } \\
\text { children only in } \\
\text { ways with which } \\
\text { each is } \\
\text { comfortable. }\end{array}$ & $\begin{array}{l}\text { Respects } \\
\text { children's } \\
\text { physical } \\
\text { boundaries. }\end{array}$ \\
\hline $\begin{array}{l}\text { 4. Provides } \\
\text { appropriate } \\
\text { feedback }\end{array}$ & $\begin{array}{l}\text { Does not } \\
\text { provide children } \\
\text { with appropriate } \\
\text { feedback. }\end{array}$ & $\begin{array}{l}\text { Uses humor } \\
\text { properly while } \\
\text { avoiding } \\
\text { sarcasm and } \\
\text { statements that } \\
\text { dampen } \\
\text { enthusiasm. }\end{array}$ & $\begin{array}{l}\text { Notes } \\
\text { accomplishments } \\
\text { with } \\
\text { encouragement, } \\
\text { e.g. "Wow, you } \\
\text { figured it out!" }\end{array}$ & $\begin{array}{l}\text { Avoids taking } \\
\text { children's } \\
\text { negative } \\
\text { statements } \\
\text { personally. }\end{array}$ & $\begin{array}{l}\text { Responds to } \\
\text { children in a } \\
\text { sensitive and } \\
\text { conscientious } \\
\text { manner. }\end{array}$ \\
\hline
\end{tabular}


Alternative Block 3 (four images)

\begin{tabular}{|c|c|c|c|c|c|}
\hline \multicolumn{6}{|c|}{ II. Montessori Philosophy/Methods } \\
\hline C. Instruction & Unaware & Beginning & Developing & Maturing & Integrating \\
\hline $\begin{array}{l}\text { 1. Lessons } \\
\text { given across } \\
\text { curriculum }\end{array}$ & $\begin{array}{l}\text { Does not give } \\
\text { at least } 3 \\
\text { Montessori } \\
\text { lessons each } \\
\text { week. }\end{array}$ & $\begin{array}{l}3-5 \text { classic } \\
\text { Montessori } \\
\text { lessons are } \\
\text { given each } \\
\text { week. }\end{array}$ & $\begin{array}{l}\text { At least } 2 \\
\text { lessons in } \\
\text { different } \\
\text { curriculum } \\
\text { areas are given } \\
\text { each day. }\end{array}$ & $\begin{array}{l}\text { At least } 3 \\
\text { lessons in a } \\
\text { variety of } \\
\text { curriculum } \\
\text { areas are given } \\
\text { each day. }\end{array}$ & $\begin{array}{l}\text { On average 3-6 } \\
\text { daily lessons } \\
\text { across } \\
\text { curriculum } \\
\text { areas are given } \\
\text { each week. }\end{array}$ \\
\hline $\begin{array}{l}\text { 2. Small and } \\
\text { flexible } \\
\text { lesson } \\
\text { grouping }\end{array}$ & $\begin{array}{l}\text { Does not give } \\
\text { small group } \\
\text { lessons with } \\
\text { flexible } \\
\text { grouping. }\end{array}$ & $\begin{array}{l}\text { Most lessons } \\
\text { given with 2-6 } \\
\text { children. }\end{array}$ & $\begin{array}{l}\text { Lessons aren't } \\
\text { repeated with } \\
\text { multiple groups } \\
\text { on the same } \\
\text { day. }\end{array}$ & $\begin{array}{l}\text { Initiates flexible } \\
\text { grouping and } \\
\text { invites an } \\
\text { interested child } \\
\text { to join. }\end{array}$ & $\begin{array}{l}\text { Uses small, } \\
\text { non-static } \\
\text { lesson } \\
\text { groupings } \\
\text { diverse across } \\
\text { ages, genders, } \\
\text { and abilities. }\end{array}$ \\
\hline $\begin{array}{l}\text { 3. Instructs with } \\
\text { enthusiasm }\end{array}$ & $\begin{array}{l}\text { Does not } \\
\text { instruct with } \\
\text { enthusiasm. }\end{array}$ & $\begin{array}{l}\text { Is curious and } \\
\text { eager to learn } \\
\text { with children. }\end{array}$ & $\begin{array}{l}\text { Suggests and } \\
\text { presents } \\
\text { activities with } \\
\text { enthusiasm. }\end{array}$ & $\begin{array}{l}\text { Shares } \\
\text { children's } \\
\text { excitement in } \\
\text { discovery and } \\
\text { learning. }\end{array}$ & $\begin{array}{l}\text { Instructs with } \\
\text { enthusiasm and } \\
\text { a sense of } \\
\text { wonder. }\end{array}$ \\
\hline $\begin{array}{l}\text { 4. Excites } \\
\text { interest }\end{array}$ & $\begin{array}{l}\text { Does not } \\
\text { introduce } \\
\text { Montessori } \\
\text { practices that } \\
\text { excite interest. }\end{array}$ & $\begin{array}{l}\text { Uses } \\
\text { storytelling and } \\
\text { fondness for } \\
\text { the extra- } \\
\text { ordinary to } \\
\text { foster interest. }\end{array}$ & $\begin{array}{l}\text { Facilitates 'big } \\
\text { work' and } \\
\text { 'going-out'. }\end{array}$ & $\begin{array}{l}\text { Facilitates food } \\
\text { preparation and } \\
\text { community } \\
\text { service. }\end{array}$ & $\begin{array}{l}\text { Arouses interest } \\
\text { with practices } \\
\text { geared to } 2^{\text {nd }} \\
\text { plane } \\
\text { characteristics. }\end{array}$ \\
\hline $\begin{array}{l}\text { 5. Facilitates } \\
\text { research }\end{array}$ & $\begin{array}{l}\text { Does not } \\
\text { facilitate } \\
\text { independent } \\
\text { investigations. }\end{array}$ & $\begin{array}{l}\text { Limits provided } \\
\text { information to } \\
\text { encourage } \\
\text { child inquiry. }\end{array}$ & $\begin{array}{l}\text { Facilitates self- } \\
\text { initiated projects } \\
\text { with how-to } \\
\text { lessons. }\end{array}$ & $\begin{array}{l}\text { Uses } \\
\text { questioning to } \\
\text { spur further } \\
\text { investigation. }\end{array}$ & $\begin{array}{l}\text { Provides time, } \\
\text { motivation, and } \\
\text { resources } \\
\text { essential for in- } \\
\text { depth research. }\end{array}$ \\
\hline $\begin{array}{l}\text { 6. Adapts public } \\
\text { school } \\
\text { requirements }\end{array}$ & $\begin{array}{l}\text { Does not } \\
\text { appropriately } \\
\text { adapt public } \\
\text { school } \\
\text { requirements. }\end{array}$ & $\begin{array}{l}\text { Math lessons } \\
\text { incorporate } \\
\text { public school } \\
\text { terminology. }\end{array}$ & $\begin{array}{l}\text { Public school } \\
\text { lessons are } \\
\text { short, hands-on } \\
\text { and } \\
\text { collaborative. }\end{array}$ & $\begin{array}{l}\text { Adapts public } \\
\text { school } \\
\text { curriculum to } \\
\text { children's } \\
\text { needs, interests } \\
\text { and abilities. }\end{array}$ & $\begin{array}{l}\text { Required public } \\
\text { school lessons } \\
\text { resemble } \\
\text { Montessori } \\
\text { presentations. }\end{array}$ \\
\hline $\begin{array}{l}\text { 7. Honors self- } \\
\text { correction }\end{array}$ & $\begin{array}{l}\text { Does not } \\
\text { enable children } \\
\text { to correct their } \\
\text { own work. }\end{array}$ & $\begin{array}{l}\text { Has a friendly } \\
\text { attitude toward } \\
\text { mistakes. }\end{array}$ & $\begin{array}{l}\text { Allows children } \\
\text { to correct their } \\
\text { own work. }\end{array}$ & $\begin{array}{l}\text { Assures that } \\
\text { activities have a } \\
\text { build-in control } \\
\text { of error. }\end{array}$ & $\begin{array}{l}\text { Treats mistakes } \\
\text { and self- } \\
\text { correction as } \\
\text { essential to } \\
\text { learning. }\end{array}$ \\
\hline
\end{tabular}




\begin{tabular}{|c|c|c|c|c|c|}
\hline \multicolumn{6}{|c|}{ II. Montessori Philosophy/Methods } \\
\hline E. Environment & Unaware & Beginning & Developing & Maturing & Integrating \\
\hline $\begin{array}{l}\text { 1. Maintains the } \\
\text { classroom }\end{array}$ & $\begin{array}{l}\text { Does not help } \\
\text { maintain the } \\
\text { environment. }\end{array}$ & $\begin{array}{l}\text { Models care } \\
\text { of the } \\
\text { classroom. }\end{array}$ & $\begin{array}{l}\text { Reinforces } \\
\text { procedures for } \\
\text { classroom } \\
\text { maintenance. }\end{array}$ & $\begin{array}{l}\text { Regularly } \\
\text { monitors } \\
\text { children's care } \\
\text { of the } \\
\text { environment. }\end{array}$ & $\begin{array}{l}\text { Supports } \\
\text { children in } \\
\text { ongoing } \\
\text { classroom } \\
\text { maintenance. }\end{array}$ \\
\hline $\begin{array}{l}\text { 2. Maintains } \\
\text { materials }\end{array}$ & $\begin{array}{l}\text { Does not } \\
\text { adequately } \\
\text { maintain } \\
\text { classroom } \\
\text { materials. }\end{array}$ & $\begin{array}{l}\text { Begins to } \\
\text { monitor } \\
\text { materials for } \\
\text { completeness }\end{array}$ & $\begin{array}{l}\text { Makes sure } \\
\text { materials are in } \\
\text { good repair. }\end{array}$ & $\begin{array}{l}\text { Mends and } \\
\text { returns broken } \\
\text { or incomplete } \\
\text { materials in a } \\
\text { timely manner. }\end{array}$ & $\begin{array}{l}\text { Assures } \\
\text { materials are } \\
\text { complete and in } \\
\text { good working } \\
\text { order. }\end{array}$ \\
\hline $\begin{array}{l}\text { 3. Prepares the } \\
\text { environment }\end{array}$ & $\begin{array}{l}\text { Does not } \\
\text { participate in } \\
\text { classroom } \\
\text { preparation and } \\
\text { modification. }\end{array}$ & $\begin{array}{l}\text { Helps set up } \\
\text { the classroom } \\
\text { each day. }\end{array}$ & $\begin{array}{l}\text { Notices when a } \\
\text { classroom } \\
\text { change could } \\
\text { meet children's } \\
\text { needs. }\end{array}$ & $\begin{array}{l}\text { Regularly } \\
\text { adjusts the } \\
\text { environment to } \\
\text { meet children's } \\
\text { needs. }\end{array}$ & $\begin{array}{l}\text { Participates in } \\
\text { ongoing } \\
\text { classroom } \\
\text { preparation and } \\
\text { modification. }\end{array}$ \\
\hline $\begin{array}{l}\text { 4. Promotes } \\
\text { safety }\end{array}$ & $\begin{array}{l}\text { Does not } \\
\text { consistently } \\
\text { assure a safe } \\
\text { environment. }\end{array}$ & $\begin{array}{l}\text { Knows } \\
\text { classroom } \\
\text { and school } \\
\text { safety and } \\
\text { emergency } \\
\text { procedures. }\end{array}$ & $\begin{array}{l}\text { Models safe } \\
\text { handling of } \\
\text { matches, } \\
\text { dangerous } \\
\text { substances, etc. }\end{array}$ & $\begin{array}{l}\text { Addresses } \\
\text { potential } \\
\text { classroom and } \\
\text { 'going out' } \\
\text { safety hazards. }\end{array}$ & $\begin{array}{l}\text { Maintains safety } \\
\text { in and out of the } \\
\text { classroom. }\end{array}$ \\
\hline $\begin{array}{l}\text { 5. Promotes } \\
\text { health }\end{array}$ & $\begin{array}{l}\text { Does not } \\
\text { maintain a } \\
\text { healthy } \\
\text { environment. }\end{array}$ & $\begin{array}{l}\text { Models } \\
\text { cleanliness } \\
\text { and safe food } \\
\text { handling. }\end{array}$ & $\begin{array}{l}\text { Administers } \\
\text { basic first aid } \\
\text { and helps } \\
\text { children } \\
\text { maintain clean } \\
\text { animal cages. }\end{array}$ & $\begin{array}{l}\text { Implements } \\
\text { health } \\
\text { promotion } \\
\text { strategies and } \\
\text { assists children } \\
\text { with personal } \\
\text { hygiene. }\end{array}$ & $\begin{array}{l}\text { Appropriately } \\
\text { reinforces } \\
\text { classroom } \\
\text { health and } \\
\text { disease } \\
\text { prevention } \\
\text { procedures. }\end{array}$ \\
\hline $\begin{array}{l}\text { 6. Implements } \\
\text { routines }\end{array}$ & $\begin{array}{l}\text { Does not } \\
\text { implement } \\
\text { classroom } \\
\text { routines. }\end{array}$ & $\begin{array}{l}\text { Warmly } \\
\text { welcomes } \\
\text { children and } \\
\text { is familiar with } \\
\text { classroom } \\
\text { routines. }\end{array}$ & $\begin{array}{l}\text { Supervises } \\
\text { classroom } \\
\text { clean-up, } \\
\text { bathroom use } \\
\text { and self-serve } \\
\text { snack. }\end{array}$ & $\begin{array}{l}\text { Facilitates calm, } \\
\text { quiet and } \\
\text { orderly } \\
\text { transitions. }\end{array}$ & $\begin{array}{l}\text { Appropriately } \\
\text { implements } \\
\text { classroom } \\
\text { routines. }\end{array}$ \\
\hline $\begin{array}{l}\text { 7. Organizes the } \\
\text { classroom }\end{array}$ & $\begin{array}{l}\text { Does not } \\
\text { maintain a well- } \\
\text { organized } \\
\text { classroom. }\end{array}$ & $\begin{array}{l}\text { Avoids over- } \\
\text { crowded } \\
\text { shelves and } \\
\text { adding } \\
\text { extraneous } \\
\text { materials. }\end{array}$ & $\begin{array}{l}\text { Maintains } \\
\text { logical material } \\
\text { groupings and } \\
\text { easy access to } \\
\text { materials. }\end{array}$ & $\begin{array}{l}\text { De-clutters and } \\
\text { rotates cultural } \\
\text { materials as } \\
\text { appropriate. }\end{array}$ & $\begin{array}{l}\text { Maintains an } \\
\text { orderly, } \\
\text { uncluttered } \\
\text { environment. }\end{array}$ \\
\hline $\begin{array}{l}\text { 8. Attends to } \\
\text { aesthetics }\end{array}$ & $\begin{array}{l}\text { Does not help } \\
\text { sustain an } \\
\text { aesthetically } \\
\text { pleasing } \\
\text { classroom. }\end{array}$ & $\begin{array}{l}\text { Avoids } \\
\text { commercial } \\
\text { enhancement } \\
\text { s and over- } \\
\text { decorating. }\end{array}$ & $\begin{array}{l}\text { Beautifies the } \\
\text { classroom with } \\
\text { simple } \\
\text { decorations and } \\
\text { items from } \\
\text { nature. }\end{array}$ & $\begin{array}{l}\text { Regularly } \\
\text { exhibits and } \\
\text { rotates } \\
\text { children's } \\
\text { displays and art } \\
\text { work. }\end{array}$ & $\begin{array}{l}\text { Maintains an } \\
\text { aesthetically } \\
\text { pleasing } \\
\text { environment. }\end{array}$ \\
\hline
\end{tabular}




\begin{tabular}{|c|c|c|c|c|c|}
\hline \multicolumn{6}{|c|}{ IV. The Social/Emotional Environment } \\
\hline A. Atmosphere & Unaware & Beginning & Developing & Maturing & Integrating \\
\hline $\begin{array}{l}\text { 1. Maintains } \\
\text { acceptable } \\
\text { noise level }\end{array}$ & $\begin{array}{l}\text { Does not } \\
\text { maintain an } \\
\text { acceptable } \\
\text { noise level. }\end{array}$ & $\begin{array}{l}\text { Begins to use a } \\
\text { low voice and } \\
\text { allows } \\
\text { conversation. }\end{array}$ & $\begin{array}{l}\text { Avoids using } \\
\text { "shhh" and } \\
\text { reprimanding } \\
\text { children who } \\
\text { converse } \\
\text { loudly. }\end{array}$ & $\begin{array}{l}\text { Avoids whole } \\
\text { class quieting, } \\
\text { uses targeted } \\
\text { problem solving } \\
\text { instead. }\end{array}$ & $\begin{array}{l}\text { Addresses noise } \\
\text { issues through } \\
\text { modeling and } \\
\text { problem solving. }\end{array}$ \\
\hline $\begin{array}{l}\text { 2. Supports } \\
\text { conflict } \\
\text { resolution }\end{array}$ & $\begin{array}{l}\text { Does not } \\
\text { support } \\
\text { children's } \\
\text { conflict } \\
\text { resolution. }\end{array}$ & $\begin{array}{l}\text { Helps children } \\
\text { negotiate } \\
\text { simple } \\
\text { disagreements. }\end{array}$ & $\begin{array}{l}\text { Avoids } \\
\text { involvement or } \\
\text { taking sides in } \\
\text { children's } \\
\text { conflicts. }\end{array}$ & $\begin{array}{l}\text { Comforts each } \\
\text { child in a dispute } \\
\text { under- standing } \\
\text { both are upset. }\end{array}$ & $\begin{array}{l}\text { Provides time } \\
\text { and support for } \\
\text { conflict resolution } \\
\text { based on best } \\
\text { practice. }\end{array}$ \\
\hline $\begin{array}{l}\text { 3. Builds } \\
\text { community }\end{array}$ & $\begin{array}{l}\text { Does not } \\
\text { build } \\
\text { community in } \\
\text { the } \\
\text { classroom. }\end{array}$ & $\begin{array}{l}\text { Helps children } \\
\text { organize and } \\
\text { run class } \\
\text { meetings. }\end{array}$ & $\begin{array}{l}\text { Supports whole } \\
\text { group activities } \\
\text { (art exhibits } \\
\text { class } \\
\text { newsletter, } \\
\text { etc.). }\end{array}$ & $\begin{array}{l}\text { Supports special } \\
\text { events and } \\
\text { productions } \\
\text { (plays, } \\
\text { musical/dance } \\
\text { performances, } \\
\text { etc.) }\end{array}$ & $\begin{array}{l}\text { Develops } \\
\text { community } \\
\text { through well- } \\
\text { managed } \\
\text { collaborative } \\
\text { activities. }\end{array}$ \\
\hline $\begin{array}{l}\text { 4. Nurtures } \\
\text { creative } \\
\text { expression }\end{array}$ & $\begin{array}{l}\text { Does not } \\
\text { nurture } \\
\text { creative } \\
\text { expression. }\end{array}$ & $\begin{array}{l}\text { Encourages } \\
\text { children to } \\
\text { decorate their } \\
\text { work. }\end{array}$ & $\begin{array}{l}\text { Begins to } \\
\text { provide } \\
\text { multicultural } \\
\text { creative arts } \\
\text { instruction. }\end{array}$ & $\begin{array}{l}\text { Infuses } \\
\text { academics with } \\
\text { opportunities for } \\
\text { handwork and } \\
\text { creative } \\
\text { expression. }\end{array}$ & $\begin{array}{l}\text { Cultivates } \\
\text { creativity and an } \\
\text { arts-rich } \\
\text { classroom. }\end{array}$ \\
\hline $\begin{array}{l}\text { 5. Provides } \\
\text { experiences } \\
\text { with nature }\end{array}$ & $\begin{array}{l}\text { Does not } \\
\text { provide } \\
\text { experiences } \\
\text { with nature. }\end{array}$ & $\begin{array}{l}\text { Offers real } \\
\text { specimen for } \\
\text { exploration and } \\
\text { discovery. }\end{array}$ & $\begin{array}{l}\text { Facilitates plant } \\
\text { and animal } \\
\text { care. }\end{array}$ & $\begin{array}{l}\text { Arranges outdoor } \\
\text { observation and } \\
\text { sample collection } \\
\text { for classification. }\end{array}$ & $\begin{array}{l}\text { Offers frequent } \\
\text { and varied } \\
\text { experiences with } \\
\text { nature. }\end{array}$ \\
\hline $\begin{array}{l}\text { 6. Provides a } \\
\text { foundation } \\
\text { for cosmic } \\
\text { education }\end{array}$ & $\begin{array}{l}\text { Does not } \\
\text { provide a } \\
\text { foundation for } \\
\text { cosmic } \\
\text { education. }\end{array}$ & $\begin{array}{l}\text { Assures } \\
\text { children are } \\
\text { given the } \\
\text { Creation of the } \\
\text { Universe story. }\end{array}$ & $\begin{array}{l}\text { Assures the } \\
\text { Great Lessons/ } \\
\text { Stories are } \\
\text { presented. }\end{array}$ & $\begin{array}{l}\text { Assures } \\
\text { fundamental } \\
\text { needs and } \\
\text { interdependencies } \\
\text { are examined. }\end{array}$ & $\begin{array}{l}\text { Emphasizes } \\
\text { meaningful } \\
\text { contribution and } \\
\text { the } \\
\text { interconnected- } \\
\text { ness of all things. }\end{array}$ \\
\hline
\end{tabular}




\begin{tabular}{|c|c|c|c|c|c|}
\hline \multicolumn{6}{|c|}{ IV. The Social/Emotional Environment } \\
\hline B. Sensitivity & Unaware & Beginning & Developing & Maturing & Integrating \\
\hline $\begin{array}{l}\text { 1. Sensitive to } \\
\text { feelings }\end{array}$ & $\begin{array}{l}\text { Does not } \\
\text { consistently } \\
\text { show sensitivity } \\
\text { to children's } \\
\text { feeling. }\end{array}$ & $\begin{array}{l}\text { Notices when } \\
\text { feelings have } \\
\text { been hurt or a } \\
\text { child is out of } \\
\text { sorts. }\end{array}$ & $\begin{array}{l}\text { Shows concern } \\
\text { toward an upset } \\
\text { child and } \\
\text { acknowledges } \\
\text { his/her feelings. }\end{array}$ & $\begin{array}{l}\text { Remains calm } \\
\text { when strong } \\
\text { emotions are } \\
\text { expressed. }\end{array}$ & $\begin{array}{l}\text { Helps each } \\
\text { child feel safe } \\
\text { and supported } \\
\text { especially } \\
\text { during } \\
\text { emotionally } \\
\text { intense } \\
\text { situations. }\end{array}$ \\
\hline $\begin{array}{l}\text { 2. Avoids } \\
\text { embarrass- } \\
\text { ing children }\end{array}$ & $\begin{array}{l}\text { Does not avoid } \\
\text { embarrassing } \\
\text { children. }\end{array}$ & $\begin{array}{l}\text { Avoids talking } \\
\text { about a child } \\
\text { near the child or } \\
\text { others. }\end{array}$ & $\begin{array}{l}\text { Approaches a } \\
\text { child prior to } \\
\text { having a } \\
\text { conversation. }\end{array}$ & $\begin{array}{l}\text { Discusses } \\
\text { issues with a } \\
\text { child calmly and } \\
\text { away from } \\
\text { others. }\end{array}$ & $\begin{array}{l}\text { Is discreet and } \\
\text { unagitated } \\
\text { when talking } \\
\text { with and about } \\
\text { children. }\end{array}$ \\
\hline $\begin{array}{l}\text { 3. Adapts } \\
\text { activities of } \\
\text { interest }\end{array}$ & $\begin{array}{l}\text { Does not adapt } \\
\text { activities of } \\
\text { interest to a } \\
\text { child's ability } \\
\text { level. }\end{array}$ & $\begin{array}{l}\text { Avoids telling a } \\
\text { child he/she } \\
\text { isn't ready for } \\
\text { an activity of } \\
\text { interest. }\end{array}$ & $\begin{array}{l}\text { Suggests } \\
\text { alternatives for } \\
\text { work a child is } \\
\text { interested in but } \\
\text { not yet ready } \\
\text { for. }\end{array}$ & $\begin{array}{l}\text { Able to adapt } \\
\text { an activity of } \\
\text { interest to a } \\
\text { child's level. }\end{array}$ & $\begin{array}{l}\text { Recognizes and } \\
\text { capitalizes on } \\
\text { teachable } \\
\text { moments. }\end{array}$ \\
\hline
\end{tabular}

Final Overall Image (all participants)

\section{Montessori Elementary Teacher Coaching Tool \\ Components of Practice Considered}

\begin{tabular}{|c|c|c|c|c|c|c|}
\hline \multicolumn{4}{|c|}{ Classroom Leadership } & \multicolumn{3}{|c|}{ Professional Behavior } \\
\hline \multicolumn{2}{|l|}{ Overview } & \multicolumn{2}{|c|}{ Redirection } & \multicolumn{2}{|c|}{ Demeanor } & Conduct \\
\hline \multicolumn{2}{|c|}{$\begin{array}{l}\text { - } \text { Positions with back to a wall } \\
\text { - Scans the room } \\
\text { - } \text { Listens } \\
\text { - } \text { Balances adults in the room } \\
\text { - } \\
\text { Panionatizes assistance }\end{array}$} & \multicolumn{2}{|c|}{$\begin{array}{l}\text { - Implements rules and } \\
\text { procedures } \\
\text { - } \quad \text { Enables self-correction } \\
\text { - } \quad \text { Is nonjudgmental } \\
\text { - } \text { Monitors redirection }\end{array}$} & \multicolumn{2}{|c|}{$\begin{array}{l}\text { - } \text { Appropriate dress } \\
\text { - Positive attitude } \\
\text { - Professional commitment } \\
\text { - Wants to improve professionally }\end{array}$} & $\begin{array}{ll}\text { - } & \text { Moves calmly } \\
\text { - } & \text { Listens carefully } \\
\text { - } & \text { Touches respectfully } \\
\text { - } & \text { Provides appropriate feedback }\end{array}$ \\
\hline \multicolumn{7}{|c|}{ Montessori Philosophy/ Methods } \\
\hline \multicolumn{3}{|c|}{ Independence } & \multicolumn{2}{|c|}{ Instruction } & Observation & Environment \\
\hline $\begin{array}{l}\text { Facilitates choice with } \\
\text { lessons } \\
\text { - } \text { Promotes co-activity } \\
\text { - } \text { work choice } \\
\text { - Fosters choice through } \\
\text { procedures } \\
\text { - Promotes choice with } \\
\text { material availability }\end{array}$ & \multicolumn{2}{|c|}{ 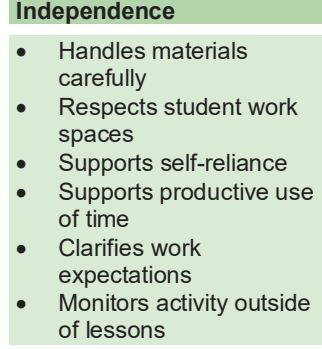 } & \multicolumn{2}{|c|}{$\begin{array}{l}\text { - Lessons given across } \\
\text { curriculum } \\
\text { - Small and flexible lesson } \\
\text { grouping } \\
\text { - } \text { Instructs with } \\
\text { enthusiasm } \\
\text { - Excites interest } \\
\text { - Facilitates research } \\
\text { - } \text { Adapts public school } \\
\text { requirements } \\
\text { - Honors self-correction }\end{array}$} & $\begin{array}{ll}\text { - } & \text { Records observatior } \\
\text { - } & \text { Utilizes recorded } \\
\text { observations } \\
\text { - } & \text { Observes objectively } \\
\text { - } & \text { Records objectively }\end{array}$ & $\begin{array}{l}\text { - } \text { Maintains the classroom } \\
\text { - } \quad \text { Paintains materials } \\
\text { - } \text { environment } \\
\text { - } \text { Promotes safety } \\
\text { - } \text { Implements routines } \\
\text { - } \text { Organizes the classroom } \\
\text { - } \text { Attends to aesthetics }\end{array}$ \\
\hline \multicolumn{4}{|c|}{ Presentations } & \multicolumn{3}{|c|}{ The Social/Emotional Environment } \\
\hline \multirow{2}{*}{\multicolumn{2}{|c|}{$\begin{array}{l}\text { Organization } \\
\text { - } \quad \text { Appropriate lessons } \\
\text { - } \quad \text { Lessons are well-prepared } \\
\text { - } \quad \text { Needed materials available } \\
\text { - } \quad \text { Materials appropriately placed }\end{array}$}} & \multicolumn{2}{|l|}{ Delivery } & \multicolumn{2}{|l|}{ Atmosphere } & Sensitivity \\
\hline & & \multicolumn{2}{|c|}{$\begin{array}{l}\text { - Uses accurate, limited language } \\
\text { - } \quad \text { moves accurate, precise } \\
\text { - } \quad \text { Lessons are interactive } \\
\text { - } \quad \text { Modifies lesson pacing } \\
\text { - } \quad \text { Connects with children } \\
\text { - } \quad \text { Checks for understanding } \\
\text { - } \quad \text { Offers follow-up suggestions }\end{array}$} & \multicolumn{2}{|c|}{$\begin{array}{l}\text { - } \text { Maintains acceptable noise level } \\
\text { - Supports conflict resolution } \\
\text { - } \text { Builds community } \\
\text { - } \quad \text { Purtures creative expression } \\
\text { nature experiences with } \\
\text { - Provides a foundation for cosmic } \\
\text { education }\end{array}$} & $\begin{array}{l}\text { - Sensitive to feelings } \\
\text { - Avoids embarrassing children } \\
\text { - Adapts activities of interest }\end{array}$ \\
\hline
\end{tabular}




\section{Appendix B: Refined MCT-EL Rubric}

\section{Montessori Coaching Tool Elementary Rubric}

Successful Montessori teaching requires the development of specific skills and competencies that reflect quality practice. Designed as a selfreflection tool for early-career teachers, the Montessori Coaching Tool Elementary (MCT-EL) rubric describes the proficiencies that potentially make up this skill set at the Elementary level and outlines how these abilities may develop over time. Although the rubric was initially based on Montessori and expert writings, developer research and experience, and well-documented practices, input from a highly experienced group of Montessori teacher educators was used to substantially improve the tool. The expert feedback made it possible to identify areas of consensus and to develop the rubric into a comprehensive framework of Montessori Elementary teaching expectations. While further research is planned to validate the tool in practice, the MCT-EL rubric is made available here to support teacher selfreflection, formative feedback, and the mentoring conversations that occur between early-career Montessori Elementary teachers and Montessori coaches.

\section{Components of Practice}

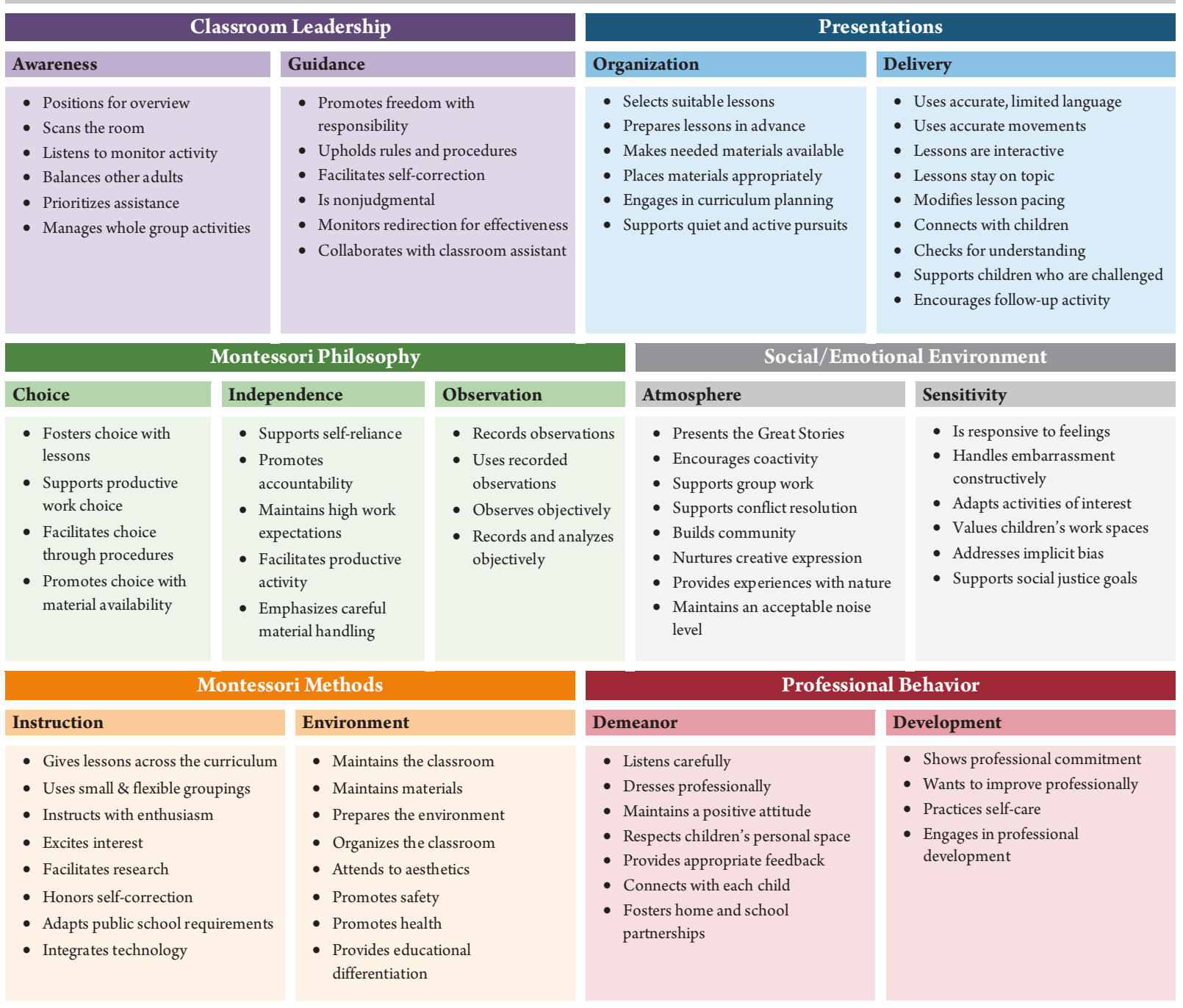




\section{Montessori Coaching Tool-Elementary Rubric}

\section{Classroom Leadership}

\section{A. Awareness}

1. Positions for overview Facilitates overview by positioning with the back toward a wall.

2. Scans the room Scans as needed to maintain classroom awareness.

3. Listens to monitor activity Listens to discreetly monitor children's activity.

4. Balances other adults Works together with other adults to safeguard the classroom.

5. Prioritizes assistance Bases assistance on whole class awareness.

6. Manages whole group activities Carefully selected whole group activities are well run, short, and enjoyable.

\section{B. Guidance}

1. Promotes freedom with responsibility Helps each child balance freedom with responsibility.

2. Upholds rules and procedures Rules and procedures are effectively and impartially communicated and supported.

3. Facilitates self-correction Enables self-correction with prompts and problem solving while avoiding power struggles.

4. Is nonjudgmental Draws nonjudgmental conclusions based on factual information.

5. Monitors redirection for effectiveness Dependably and productively monitors redirection.

6. Collaborates with classroom assistant Builds a trusting, collaborative relationship with the classroom assistant.

Unaware
At times positioning enables
overview of half the
classroom or less.
Only occasionally looks up
or around the classroom.
Remains occupied after loud
or unusual sounds are made.
Has limited overview when
other adults teach/leave the
room.

Continues a whole group activity despite children's diverted attention.

Beginning
Usually avoids facing a wa
or shelf during lessons.
Begins to scan the room
between lessons.
Turns toward loud sounds.
Is becoming aware when
other adults are teaching
have left the room.
Notices assistance is needed
by nearby children and
approaches.
Maintains the group's
attention while reading a
story, singing, etc.

\section{Backis towarda wall while}

Back is toward a wall while observing and during most lessons.

More consistently looks up and around during lessons.

Turns toward unusual sounds.

Begins to position away from other adults and for 'one up, one down.'

Monitors children within 15 feet; moves from one group to the next.

Attains attention before a group activity and holds attention for at least 10 minutes.

\section{Maturing}

Consistently positions with the back to a wall, near room edges.

Incorporates room scans into and between lessons as needed for overview.

Notices and responds to sounds suggesting unsafe or disruptive behavior.

Repositions to balance other adults, and checks in with them verbally or nonverbally.

Usually scans the room before determining where to assist.

Can lead the whole group for at least 15 minutes regaining attention as needed.

At times is overly permissive

or more restrictive than necessary.

Inconsistently supports rule and procedure compliance.

\section{Occasionally nags or} motivates nonconstructively, e.g., "No...," "That's wrong," "Shhh," "You need to...”.

Some conclusions about behavior are made as snap judgments or assumptions.

Provides redirection then focuses attention elsewhere.

Is inconsistent in support or direction provided to the assistant.

Developing \\ Beginning}

With children, clearly defines

freedoms, and

responsibilities.

Gives grace and courtesy

lessons and begins to uphold rules and procedures.

States what to do rather than negative directives, e.g., "walk" instead of "don't run."

Uses observation to help ground conclusions in fact.

Begins to observe a child's response after redirection.

Clarifies the assistant's responsibilities and reasons behind classroom practices.
Expands freedoms offered

with demonstrated responsibility.

Refers to established limits when addressing unfavorable actions.

Questions and points things out in a matter of fact way, e.g., "Is that your pencil?" "I notice..."

Uses open-ended questions to draw factual conclusions, e.g., "Tell me about..."

More consistently assesses if redirection has been effective.

Begins to provide the assistant with ongoing communication and constructive guidance.
Checks in and problem solves with children to jointly form accurate conclusions.

Impartially monitors redirection encouraging compliance when needed.

Consults with the assistant to share, plan, and address issues. 


\section{Montessori Philosophy}

A. Choice

1. Fosters choice with lessons Offers many optional, small group lessons to facilitate choice.

2. Supports productive work choice Establishes systems to help children select suitable activities.

3. Facilitates choice through procedures Enacts procedures supporting every-day decisionmaking opportunities.

4. Promotes choice with material availability Supports productive choice with a full range of Montessori Elementary materials.

\section{B. Independence}

1. Supports self-reliance Recognizes when children need help or can do activities themselves.

2. Promotes accountability Supports each child's activity-goals with work journals and conferences.

3. Maintains high work expectations Holds the expectation that meaningful work will be done by all.

4. Facilitates productive activity Establishes systems to help assure productive use of time.

5. Emphasizes careful material handling Supports careful material retrieval, use, and replacement.

\begin{tabular}{|c|c|c|}
\hline Beginning & Developing & Maturing \\
\hline $\begin{array}{l}\text { Invites children to } \\
\text { participate in lessons. }\end{array}$ & $\begin{array}{l}\text { Gives many small group } \\
\text { lessons that pique children's } \\
\text { interests. }\end{array}$ & $\begin{array}{l}\text { Helps children develop work } \\
\text { plans with lessons inspiring } \\
\text { productive work. }\end{array}$ \\
\hline $\begin{array}{l}\text { Alternately selects work and } \\
\text { offers choice for a child unable } \\
\text { to choose. }\end{array}$ & $\begin{array}{l}\text { Models weighing pros and } \\
\text { cons of choices; increases } \\
\text { options as ability to choose } \\
\text { develops. }\end{array}$ & $\begin{array}{l}\text { Strategically groups and pairs } \\
\text { children to help stimulate } \\
\text { activity selection. }\end{array}$ \\
\hline $\begin{array}{l}\text { Children choose their } \\
\text { seating, work partners, snack } \\
\text { time, etc. }\end{array}$ & $\begin{array}{l}\text { Children organize their time } \\
\text { during a 3-hr uninterrupted } \\
\text { work period. }\end{array}$ & $\begin{array}{l}\text { Children engage in } \\
\text { community decision-making } \\
\text { and problem solving. }\end{array}$ \\
\hline
\end{tabular}
made that children could have made themselves.

Montessori materials are limited or misaligned with children's ability and needs.

Makes age-appropriate manipulative and

timeline/chart materials available.

Beginning

Unaware

Occasionally completes work, helps, or tells what to do when not needed.

Has yet to use work journals and conferences to support accountability

At times praises and recognizes children for simple tasks.

Tends to allow unproductive activity to continue.

Misses when 2 materials are carried or are used in an unsafe or damaging way.

\section{Observes before offering assistance.}

Helps children maintain work journals and understand why doing so is important.

Conveys the expectation that productive work must be done.

Begins to recognize when time is not being used constructively.

Models appropriate handling of materials.
Makes experiment, followup, and large timeline making materials available.
Regularly rotates materials, books, and resources to meet children's interests and needs.

Developing Maturing

Asks problem solving Monitors activity discreetly, questions when children face assists briefly, and checks difficulties.

back in as needed.

Meets regularly 1-on-1 with Monitors agreed-on goals

children to review journals and mutually creates and plan activities.

Uses challenging but achievable activities to uphold high expectations.

Observes, identifies, and begins to address reasons behind unproductive activity.

Reviews how to carry materials when needed. solutions when plans fall short.

Uses self-reflection to assess if expectations are held without bias or prejudice.

Confers with children and strategizes together to address unproductive use of time.

Consistently addresses when materials aren't used, carried, or returned properly.

\begin{tabular}{|c|c|c|c|c|}
\hline C. Observation & Unaware & Beginning & Developing & Maturing \\
\hline $\begin{array}{l}\text { 1. Records observations Records } \\
\text { observations daily using an efficient } \\
\text { record keeping system. }\end{array}$ & $\begin{array}{l}\text { Primarily keeps a mental } \\
\text { record of lessons given and } \\
\text { children's activities. }\end{array}$ & $\begin{array}{l}\text { Records observations at least } \\
\text { several times a week. }\end{array}$ & $\begin{array}{l}\text { Records observations } \\
\text { everyday and begins to use a } \\
\text { record keeping system. }\end{array}$ & $\begin{array}{l}\text { Records lessons right after } \\
\text { they're given using an } \\
\text { efficient record-keeping } \\
\text { system. }\end{array}$ \\
\hline $\begin{array}{l}\text { 2. Uses recorded observations } \\
\text { Utilizes observations to plan, set } \\
\text { goals, modify the classroom, and } \\
\text { create reports. }\end{array}$ & $\begin{array}{l}\text { Uses recollection to plan } \\
\text { lessons and modify the } \\
\text { classroom. }\end{array}$ & $\begin{array}{l}\text { Begins to review notes for } \\
\text { lesson planning purposes. }\end{array}$ & $\begin{array}{l}\text { Uses recorded observations } \\
\text { to plan lessons and adjust the } \\
\text { environment. }\end{array}$ & $\begin{array}{l}\text { Uses notes for student goal } \\
\text { setting and to generate } \\
\text { reports. }\end{array}$ \\
\hline $\begin{array}{l}\text { 3. Observes objectively Observes and } \\
\text { describes behavior objectively } \\
\text { without evaluation or attribute. }\end{array}$ & $\begin{array}{l}\text { Perceives some behavior } \\
\text { subjectively by evaluating or } \\
\text { attributing cause. }\end{array}$ & $\begin{array}{l}\text { Begins to describe behavior } \\
\text { factually, e.g., The boy throws } \\
\text { the hat quickly. }\end{array}$ & $\begin{array}{l}\text { Describes behavior with-out } \\
\text { evaluation, e.g., The girl talks } \\
\text { loudly, rather than The girl is } \\
\text { rude. }\end{array}$ & $\begin{array}{l}\text { Describes behavior without } \\
\text { attributing cause, e.g., The } \\
\text { girl cries, rather than The girl } \\
\text { is sad. }\end{array}$ \\
\hline $\begin{array}{l}\text { 4. Records and analyzes objectively } \\
\text { Records impartially and draws } \\
\text { factually based conclusions } \\
\text { grounded in theory. }\end{array}$ & $\begin{array}{l}\text { Periodically draws behavioral } \\
\text { conclusions based on past } \\
\text { experiences. }\end{array}$ & $\begin{array}{l}\text { While note taking avoids } \\
\text { labels and absolutes, e.g., } \\
\text { needy, gifted; never, always, } \\
\text { every. }\end{array}$ & $\begin{array}{l}\text { Can record what is said and } \\
\text { done in a play-by-play } \\
\text { manner. }\end{array}$ & $\begin{array}{l}\text { Begins to use developmental } \\
\text { theory to interpret recorded } \\
\text { behavior patterns. }\end{array}$ \\
\hline
\end{tabular}




\section{Montessori Methods}

\section{A. Instruction}

1. Gives lessons a cross the curriculum Each week, 5-8 daily lessons are given across curriculum areas.

2. Uses small and flexible groupings Uses small, non-static lesson groupings diverse across ages, genders, and abilities.

3. Instructs with enthusiasm Teaches with enthusiasm, enjoyment, and a sense of wonder.

4. Excites interest Arouses interest with practices geared to $2^{\text {nd }}$ plane characteristics.

5. Facilitates research Provides time, motivation, instruction, and resources essential for in-depth research.

6. Honors self-correction Uses control of error and reflection to foster learning from mistakes.

\section{Adapts public school} requirements Adapts auxiliary public school content to children's needs, interests, and abilities.

8. Integrates technology Integrates technologies that complement the curriculum and develop digital fluency.

\begin{tabular}{ll}
\multicolumn{1}{c}{ Unaware } & \multicolumn{1}{c}{ Beginning } \\
$\begin{array}{ll}1 \text { or } 2 \text { lessons are given each } \\
\text { day. }\end{array}$ & $\begin{array}{l}\text { At least } 12 \text { Montessori } \\
\text { lessons are given each week. }\end{array}$ \\
\hline
\end{tabular}

Regularly gives lessons to 7 or more children.

Sometimes appears

indifferent or uncomfortable

during lessons.

Lessons consist primarily of material use instruction or directional statements.

Classroom activity focuses on materials and basic follow-up exercises.

Inspects or corrects each child's finished work.

Presents public school content in a public schoo manner.

Is reluctant or has yet to incorporate technologies in the classroom.
Most lessons given with 2 to 6 children.

Is curious and eager to learn with children.

Uses storytelling and fondness for heroes and the extraordinary to foster interest.

Limits the amount of information given to encourage child inquiry.

Assures activities have control of error; has a respectful attitude toward mistakes.

Posts the public school curriculum, and lessons incorporate public school terminology.

Sets technology use guidelines, and teaches basic skills, e.g., key- boarding.

\section{Developing}

At least 3 lessons in differen curriculum areas are given each day.

Lessons aren't repeated with multiple groups on the same day.

Suggests and presents activities with enthusiasm.

Facilitates 'big work,' and the study of etymology and calligraphy.

Facilitates self-initiated projects with sufficient time and how-to lessons.

Guides children in seeing, reflecting on, and correcting errors themselves.

Public school lessons are short, hands-on, and collaborative.

Introduces productivity tools for completing projects, e.g. word processing, graphs.
Maturing

At least 5 lessons in a variety of curriculum areas are given each day.

Initiates flexible grouping and invites an interested child to join.

Shares children's excitemen in discovery and learning.

Facilitates 'going out' and service learning.

Uses questioning and resource availability to spur further investigation.

Helps children provide one another with constructive feedback.

Required additional public school lessons resemble Montessori presentations.

Introduces digital tools to foster exploration, discovery, collaboration, and creativity.

\begin{tabular}{|c|c|c|c|c|}
\hline B. Environment & Unaware & Beginning & Developing & Maturing \\
\hline $\begin{array}{l}\text { Maintains the classroom Supports } \\
\text { children's ownership of classroom } \\
\text { maintenance. }\end{array}$ & $\begin{array}{l}\text { Establishes room care } \\
\text { procedures with little or no } \\
\text { input from children. }\end{array}$ & $\begin{array}{l}\text { Helps children devise and } \\
\text { implement a room care } \\
\text { system. }\end{array}$ & $\begin{array}{l}\text { Models and monitors care of } \\
\text { the environment. }\end{array}$ & $\begin{array}{l}\text { Helps children maintain } \\
\text { order during large, messy } \\
\text { projects. }\end{array}$ \\
\hline $\begin{array}{l}\text { Maintains materials } \\
\text { Assures materials are clean, } \\
\text { complete, and in good working } \\
\text { order. }\end{array}$ & $\begin{array}{l}\text { Some classroom materials } \\
\text { are poorly functioning, } \\
\text { incomplete, damaged, or } \\
\text { dirty. }\end{array}$ & $\begin{array}{l}\text { Begins to monitor materials } \\
\text { for cleanliness and } \\
\text { completeness. }\end{array}$ & $\begin{array}{l}\text { Makes sure materials are in } \\
\text { good repair. }\end{array}$ & $\begin{array}{l}\text { Mends and returns damaged } \\
\text { or incomplete materials in a } \\
\text { timely manner. }\end{array}$ \\
\hline $\begin{array}{l}\text { 3. Prepares the environment } \\
\text { Prepares and modifies the classroom } \\
\text { based on children's needs. }\end{array}$ & $\begin{array}{l}\text { Maintains the classroom as it } \\
\text { is, rarely making a change. }\end{array}$ & $\begin{array}{l}\text { Assures the classroom is } \\
\text { appropriately set up each } \\
\text { day. }\end{array}$ & $\begin{array}{l}\text { Begins to implement } \\
\text { classroom changes to meet } \\
\text { children's needs. }\end{array}$ & $\begin{array}{l}\text { Regularly adds/removes } \\
\text { materials or resources to } \\
\text { support children's progress. }\end{array}$ \\
\hline $\begin{array}{l}\text { 4. Organizes the classroom Maintains } \\
\text { an orderly, uncluttered environment. }\end{array}$ & $\begin{array}{l}\text { Some materials have been } \\
\text { placed haphazardly on } \\
\text { shelves. }\end{array}$ & $\begin{array}{l}\text { Avoids overcrowded shelves } \\
\text { and adding extraneous } \\
\text { materials. }\end{array}$ & $\begin{array}{l}\text { Maintains easy access to } \\
\text { materials and logical material } \\
\text { groupings. }\end{array}$ & $\begin{array}{l}\text { Accommodates evolving } \\
\text { activities and projects; } \\
\text { declutters as needed. }\end{array}$ \\
\hline $\begin{array}{l}\text { 5. Attends to aesthetics Maintains an } \\
\text { aesthetically pleasing environment. }\end{array}$ & $\begin{array}{l}\text { Some areas are heavily } \\
\text { decorated, or commercial } \\
\text { décor is prominent. }\end{array}$ & $\begin{array}{l}\text { Beautifies the classroom with } \\
\text { simple decorations and items } \\
\text { from nature. }\end{array}$ & $\begin{array}{l}\text { Regularly exhibits and } \\
\text { rotates children's displays } \\
\text { and artwork. }\end{array}$ & $\begin{array}{l}\text { Consciously uses color, } \\
\text { textures, plants, etc. to } \\
\text { invoke warmth and beautify. }\end{array}$ \\
\hline $\begin{array}{l}\text { 6. Promotes safety Encourages safety } \\
\text { in and out of the classroom. }\end{array}$ & $\begin{array}{l}\text { One or more safety issue is } \\
\text { evident, e.g., trip hazard, } \\
\text { unlocked chemicals. }\end{array}$ & $\begin{array}{l}\text { Introduces classroom and } \\
\text { school safety and emergency } \\
\text { procedures. }\end{array}$ & $\begin{array}{l}\text { Models and supports } \\
\text { children in the safe use of } \\
\text { matches, dangerous } \\
\text { substances, etc. }\end{array}$ & $\begin{array}{l}\text { Preemptively addresses } \\
\text { potential classroom, school } \\
\text { and 'going out' safety } \\
\text { hazards. }\end{array}$ \\
\hline $\begin{array}{l}\text { 7. Promotes health Consistently } \\
\text { reinforces classroom health and } \\
\text { disease prevention procedures. }\end{array}$ & $\begin{array}{l}\text { One or more health issue is } \\
\text { evident, e.g., no first-aid kit, } \\
\text { lax hand washing. }\end{array}$ & $\begin{array}{l}\text { Models and teaches } \\
\text { cleanliness and safe food } \\
\text { handling. }\end{array}$ & $\begin{array}{l}\text { Administers basic first aid } \\
\text { and helps children maintain } \\
\text { clean animal enclosures. }\end{array}$ & $\begin{array}{l}\text { Implements health } \\
\text { promotion strategies and } \\
\text { assists children with personal } \\
\text { hygiene. }\end{array}$ \\
\hline $\begin{array}{l}\text { 8. Provides educational } \\
\text { differentiation Differentiates } \\
\text { education to support children of all } \\
\text { abilities. }\end{array}$ & $\begin{array}{l}\text { Classroom practices are } \\
\text { geared toward typically } \\
\text { developing children. }\end{array}$ & $\begin{array}{l}\text { Partners with parents and } \\
\text { SPED faculty to provide } \\
\text { needed services. }\end{array}$ & $\begin{array}{l}\text { Adjusts the environment and } \\
\text { lessons to support children } \\
\text { who learn/think differently. }\end{array}$ & $\begin{array}{l}\text { Uses strengths to target areas } \\
\text { of need; provides useful } \\
\text { technologies. }\end{array}$ \\
\hline
\end{tabular}




\begin{tabular}{|c|c|c|c|c|}
\hline A. Organization & Unaware & Beginning & Developing & Maturing \\
\hline $\begin{array}{l}\text { 1. Selects suitable lessons Lessons are } \\
\text { appropriate for each child's interest, } \\
\text { experience, and ability. }\end{array}$ & $\begin{array}{l}\text { Lesson selection is based on } \\
\text { grade level or age. }\end{array}$ & $\begin{array}{l}\text { Uses albums and work plans } \\
\text { to guide lesson selection. }\end{array}$ & $\begin{array}{l}\text { Planned and spontaneous } \\
\text { lessons are based on } \\
\text { observed interest and prior } \\
\text { activity. }\end{array}$ & $\begin{array}{l}\text { Uses notes, discussions, and } \\
\text { curriculum planning to select } \\
\text { interesting lessons. }\end{array}$ \\
\hline $\begin{array}{l}\text { 2. Prepares lessons in advance } \\
\text { Lessons flow, and are clear, } \\
\text { complete, and concise. }\end{array}$ & $\begin{array}{l}\text { Gives spontaneous lessons } \\
\text { with minimal prior } \\
\text { preparation. }\end{array}$ & $\begin{array}{l}\text { Albums are consulted and } \\
\text { notes taken before giving } \\
\text { lessons. }\end{array}$ & $\begin{array}{l}\text { Refers to notes briefly and } \\
\text { unobtrusively during lessons. }\end{array}$ & $\begin{array}{l}\text { Lessons usually flow and are } \\
\text { consistent with album } \\
\text { descriptions. }\end{array}$ \\
\hline $\begin{array}{l}\text { 3. Makes needed materials available } \\
\text { All materials needed are available } \\
\text { during and after lessons. }\end{array}$ & $\begin{array}{l}\text { Materials are periodically } \\
\text { retrieved as needed during } \\
\text { lessons. }\end{array}$ & $\begin{array}{l}\text { Materials needed are on } \\
\text { hand when lessons begin. }\end{array}$ & $\begin{array}{l}\text { Materials remain available to } \\
\text { children after lessons. }\end{array}$ & $\begin{array}{l}\text { Appropriate follow-up } \\
\text { materials are made available. }\end{array}$ \\
\hline $\begin{array}{l}\text { 4. Places materials appropriately } \\
\text { Materials are accurately placed and } \\
\text { in easy reach of children during and } \\
\text { after lessons. }\end{array}$ & $\begin{array}{l}\text { At times places materials } \\
\text { haphazardly or in front of } \\
\text { themselves rather than the } \\
\text { children. }\end{array}$ & $\begin{array}{l}\text { Materials are placed in an } \\
\text { orderly layout during most } \\
\text { lessons. }\end{array}$ & $\begin{array}{l}\text { Materials are placed directly } \\
\text { in front of children during } \\
\text { most lessons. }\end{array}$ & $\begin{array}{l}\text { Material placements enable } \\
\text { successful use during and } \\
\text { once the presentation is over. }\end{array}$ \\
\hline $\begin{array}{l}\text { Engages in curriculum planning } \\
\text { Engages in short and long term } \\
\text { curriculum planning for each child. }\end{array}$ & $\begin{array}{l}\text { Lesson planning ideas have } \\
\text { yet to be written out. }\end{array}$ & $\begin{array}{l}\text { Prepares daily lesson plans } \\
\text { with room for spontaneous } \\
\text { presentations. }\end{array}$ & $\begin{array}{l}\text { Prepares weekly lesson plans } \\
\text { with flexibility. }\end{array}$ & $\begin{array}{l}\text { Engages in monthly/ } \\
\text { semester planning for each } \\
\text { child. }\end{array}$ \\
\hline $\begin{array}{l}\text { 6. Supports quiet and active pursuits } \\
\text { Supports quiet/lively activity } \\
\text { preferences with workspace options } \\
\text { and resources. }\end{array}$ & $\begin{array}{l}\text { Supports either quiet or } \\
\text { lively activities, but not both } \\
\text { at the same time. }\end{array}$ & $\begin{array}{l}\text { Provides classroom space for } \\
\text { both quiet and more spirited } \\
\text { activities. }\end{array}$ & $\begin{array}{l}\text { Offers equipment to facilitate } \\
\text { quiet, focused activity, e.g., } \\
\text { head-phones. }\end{array}$ & $\begin{array}{l}\text { Creates and implements } \\
\text { procedures for work in areas } \\
\text { adjacent to the classroom, } \\
\text { e.g., hallway. }\end{array}$ \\
\hline B. Delivery & Unaware & Beginning & Developing & Maturing \\
\hline $\begin{array}{l}\text { 1. Uses accurate, limited language } \\
\text { Language flows, and is clear, } \\
\text { accurate, and limited. }\end{array}$ & $\begin{array}{l}\text { On occasion embellishes or } \\
\text { uses imprecise or incorrect } \\
\text { language. }\end{array}$ & Speaks clearly during lessons. & $\begin{array}{l}\text { Precise, accurate language is } \\
\text { used with few } \\
\text { embellishments. }\end{array}$ & $\begin{array}{l}\text { Language flows and is } \\
\text { succinctly adapted to } \\
\text { children's responses. }\end{array}$ \\
\hline $\begin{array}{l}\text { 2. Uses accurate movements } \\
\text { Materials are precisely and correctly } \\
\text { manipulated throughout each lesson. }\end{array}$ & $\begin{array}{l}\text { Some movements are rushed } \\
\text { or inaccurate. }\end{array}$ & $\begin{array}{l}\text { Begins to move materials } \\
\text { slowly and accurately during } \\
\text { lessons. }\end{array}$ & $\begin{array}{l}\text { Uses clear, exact movements } \\
\text { without bouncing the hand. }\end{array}$ & $\begin{array}{l}\text { Carefully and accurately } \\
\text { manipulates materials during } \\
\text { lessons. }\end{array}$ \\
\hline $\begin{array}{l}\text { 3. Lessons are interactive Engages } \\
\text { children in highly interactive lessons. }\end{array}$ & $\begin{array}{l}\text { Children primarily listen and } \\
\text { observe during lessons. }\end{array}$ & $\begin{array}{l}\text { Involves children at some } \\
\text { point during lessons. }\end{array}$ & $\begin{array}{l}\text { Involves children early on } \\
\text { during lessons. }\end{array}$ & $\begin{array}{l}\text { Engages each child often in } \\
\text { each lesson. }\end{array}$ \\
\hline $\begin{array}{l}\text { 4. Lessons stay on topic Lessons stay } \\
\text { on topic and are short in duration. }\end{array}$ & $\begin{array}{l}\text { Sometimes lessons are overly } \\
\text { long or unfocused. }\end{array}$ & $\begin{array}{l}\text { Refocuses lessons that have } \\
\text { veered off course. }\end{array}$ & $\begin{array}{l}\text { Remains on topic during } \\
\text { most lessons. }\end{array}$ & $\begin{array}{l}\text { The majority of lessons are } \\
15 \text { minutes or less. }\end{array}$ \\
\hline $\begin{array}{l}\text { Modifies lesson pacing Gives well- } \\
\text { paced lessons that aren't too hard or } \\
\text { too easy. }\end{array}$ & $\begin{array}{l}\text { Continues with a lesson } \\
\text { despite indications it is too } \\
\text { basic or difficult. }\end{array}$ & $\begin{array}{l}\text { Begins to notice when a } \\
\text { lesson's pace is too fast or } \\
\text { slow. }\end{array}$ & $\begin{array}{l}\text { Modifies a lesson's pace } \\
\text { according to children's } \\
\text { responses. }\end{array}$ & $\begin{array}{l}\text { Reviews prior learning and } \\
\text { gives a prior or subsequent } \\
\text { lesson if needed. }\end{array}$ \\
\hline $\begin{array}{l}\text { 6. Connects with children Maintains } \\
\text { a connection with each child } \\
\text { throughout each lesson. }\end{array}$ & $\begin{array}{l}\text { Focuses on the lesson rather } \\
\text { than the participating } \\
\text { children. }\end{array}$ & $\begin{array}{l}\text { Begins to use facial } \\
\text { expressions to connect with } \\
\text { children. }\end{array}$ & $\begin{array}{l}\text { Acknowledges children's } \\
\text { reactions during most } \\
\text { lessons. }\end{array}$ & $\begin{array}{l}\text { Responds to children with } \\
\text { warmth and empathy. }\end{array}$ \\
\hline $\begin{array}{l}\text { 7. Checks for understanding } \\
\text { Observes and questions to assess } \\
\text { understanding during and after } \\
\text { lessons. }\end{array}$ & $\begin{array}{l}\text { Periodically gives a lesson } \\
\text { without observing, } \\
\text { questioning, or discussing. }\end{array}$ & $\begin{array}{l}\text { Asks simple questions and } \\
\text { observes material use during } \\
\text { lessons. }\end{array}$ & $\begin{array}{l}\text { Observes during and after } \\
\text { lessons to assess ability to use } \\
\text { materials. }\end{array}$ & $\begin{array}{l}\text { Checks for understanding } \\
\text { with clarifying questions and } \\
\text { discussion. }\end{array}$ \\
\hline $\begin{array}{l}\text { 8. Supports children who are } \\
\text { challenged Differentiates } \\
\text { instruction when children struggle } \\
\text { with an activity. }\end{array}$ & $\begin{array}{l}\text { At times is unaware or only } \\
\text { repeats a lesson when a child } \\
\text { exhibits difficultly. }\end{array}$ & $\begin{array}{l}\text { Recognizes when children } \\
\text { are struggling to understand } \\
\text { an activity. }\end{array}$ & $\begin{array}{l}\text { Begins to assess why children } \\
\text { are having difficulty with an } \\
\text { activity. }\end{array}$ & $\begin{array}{l}\text { Helps children challenged by } \\
\text { an activity by isolating the } \\
\text { difficulty. }\end{array}$ \\
\hline $\begin{array}{l}\text { 9. Encourages follow-up activity } \\
\text { Encourages child-designed follow-up } \\
\text { aligned with their interests and } \\
\text { ability. }\end{array}$ & $\begin{array}{l}\text { Tends to assign follow- up } \\
\text { activities or limits what can } \\
\text { be done. }\end{array}$ & $\begin{array}{l}\text { Offers follow-up options } \\
\text { based on album suggestions. }\end{array}$ & $\begin{array}{l}\text { Provides clear follow-up } \\
\text { instruction modeling what is } \\
\text { expected. }\end{array}$ & $\begin{array}{l}\text { With children, develops } \\
\text { follow-up options based on } \\
\text { their ideas and preferences. }\end{array}$ \\
\hline
\end{tabular}




\section{Social/Emotional Environment}

\begin{tabular}{|c|c|c|c|c|}
\hline A. Atmosphere & Unaware & Beginning & Developing & Maturing \\
\hline $\begin{array}{l}\text { 1. Presents the Great Stories Uses the } \\
\text { Great Stories to unify instruction, } \\
\text { inspire awe, and motivate child led } \\
\text { research. }\end{array}$ & $\begin{array}{l}\text { Gives key lessons before } \\
\text { presenting the Creation } \\
\text { Story. }\end{array}$ & $\begin{array}{l}\text { Presents the Universe } \\
\text { Creation story; begins to tell } \\
\text { other Great Stories. }\end{array}$ & $\begin{array}{l}\text { Assures children are told all } \\
\text { the Great Stories. }\end{array}$ & $\begin{array}{l}\text { Aligns key lessons with the } \\
\text { Great Stories and } \\
\text { emphasizes inter- } \\
\text { connections. }\end{array}$ \\
\hline $\begin{array}{l}\text { 2. Encourages coactivity Facilitates } \\
\text { productive coactivity, collaboration, } \\
\text { and peer instruction. }\end{array}$ & $\begin{array}{l}\text { Instruction and procedures } \\
\text { encourage individual activity. }\end{array}$ & $\begin{array}{l}\text { Table/floor arrangements } \\
\text { accommodate pairs and } \\
\text { different sized groups. }\end{array}$ & $\begin{array}{l}\text { Teaches coactivity skills so } \\
\text { children collaborate } \\
\text { productively. }\end{array}$ & $\begin{array}{l}\text { Fosters a spirit of } \\
\text { cooperation where children } \\
\text { willingly help or instruct one } \\
\text { another. }\end{array}$ \\
\hline $\begin{array}{l}\text { 3. Supports group work Establishes } \\
\text { productive, harmonious group } \\
\text { activity as the classroom norm. }\end{array}$ & $\begin{array}{l}\text { Recognizes sitting together } \\
\text { but working separately as } \\
\text { group work. }\end{array}$ & $\begin{array}{l}\text { Provides instruction } \\
\text { favorable to collaborative } \\
\text { work. }\end{array}$ & $\begin{array}{l}\text { Helps children organize and } \\
\text { share group work } \\
\text { responsibilities. }\end{array}$ & $\begin{array}{l}\text { Helps children refocus } \\
\text { unproductive group activity. }\end{array}$ \\
\hline $\begin{array}{l}\text { 4. Supports conflict resolution } \\
\text { Teaches and entrusts children to } \\
\text { resolve their own disputes. }\end{array}$ & $\begin{array}{l}\text { Misses escalating conflict, } \\
\text { takes sides, resolves the } \\
\text { conflict, etc. }\end{array}$ & $\begin{array}{l}\text { Assists children in } \\
\text { negotiating simple } \\
\text { disagreements. }\end{array}$ & $\begin{array}{l}\text { Teaches age-appropriate } \\
\text { conflict resolution skills. }\end{array}$ & $\begin{array}{l}\text { Provides time, neutrality, and } \\
\text { procedures for child lead } \\
\text { conflict resolution. }\end{array}$ \\
\hline $\begin{array}{l}\text { 5uilds community Develops } \\
\text { community through well-managed } \\
\text { collaborative activities. }\end{array}$ & $\begin{array}{l}\text { Classroom activity focuses } \\
\text { exclusively on small group } \\
\text { and individual exercises. }\end{array}$ & $\begin{array}{l}\text { Supports whole group } \\
\text { activities, e.g., class } \\
\text { newsletter, art exhibits. }\end{array}$ & $\begin{array}{l}\text { Helps children organize and } \\
\text { run class meetings. }\end{array}$ & $\begin{array}{l}\text { Supports special events and } \\
\text { productions, e.g., plays, } \\
\text { dance performances. }\end{array}$ \\
\hline $\begin{array}{l}\text { 6urtures creative expression } \\
\text { Cultivates creativity and an arts-rich } \\
\text { classroom. }\end{array}$ & $\begin{array}{l}\text { Prioritizes academics with } \\
\text { minimal emphasis on arts } \\
\text { education. }\end{array}$ & $\begin{array}{l}\text { Encourages children to } \\
\text { decorate their work. }\end{array}$ & $\begin{array}{l}\text { Begins to provide } \\
\text { multicultural creative-arts } \\
\text { instruction. }\end{array}$ & $\begin{array}{l}\text { Infuses academics with } \\
\text { opportunities for handwork } \\
\text { and creative expression. }\end{array}$ \\
\hline $\begin{array}{l}\text { 7. Provides experiences with nature } \\
\text { Offers frequent and varied } \\
\text { experiences with nature. }\end{array}$ & $\begin{array}{l}\text { Emphasizes instruction } \\
\text { about nature rather than } \\
\text { hands-on experiences. }\end{array}$ & $\begin{array}{l}\text { Facilitates plant and animal } \\
\text { care. }\end{array}$ & $\begin{array}{l}\text { Offers real specimen for } \\
\text { exploration and discovery. }\end{array}$ & $\begin{array}{l}\text { Arranges outdoor } \\
\text { adventuring and sample } \\
\text { collection/ observation for } \\
\text { classification. }\end{array}$ \\
\hline $\begin{array}{l}\text { 8. Maintains an acceptable noise } \\
\text { level Addresses noise issues through } \\
\text { modeling and problem solving. }\end{array}$ & $\begin{array}{l}\text { Quiets the class with a raised } \\
\text { voice, limiting talk, } \\
\text { reprimanding or using } \\
\text { "shhh." }\end{array}$ & $\begin{array}{l}\text { Uses a low voice and allows } \\
\text { conversation and a hum of } \\
\text { activity. }\end{array}$ & $\begin{array}{l}\text { Uses targeted problem } \\
\text { solving when the classroom } \\
\text { is too loud. }\end{array}$ & $\begin{array}{l}\text { Develops solutions with } \\
\text { children for maintaining an } \\
\text { acceptable noise level. }\end{array}$ \\
\hline B. Sensitivity & Unaware & Beginning & Developing & Maturing \\
\hline $\begin{array}{l}\text { 1. Is respon sive to feelings Helps } \\
\text { children feel heard and supported } \\
\text { when emotionally distressed. }\end{array}$ & $\begin{array}{l}\text { At times misses when } \\
\text { feelings are hurt, a child is } \\
\text { out of sorts, etc. }\end{array}$ & $\begin{array}{l}\text { Acknowledges and helps an } \\
\text { upset child identify and } \\
\text { verbalize their feelings. }\end{array}$ & $\begin{array}{l}\text { Handles strong emotions } \\
\text { calmly, not taking what is } \\
\text { said or done personally. }\end{array}$ & $\begin{array}{l}\text { Teaches children how to } \\
\text { cope with uncomfortable } \\
\text { feelings. }\end{array}$ \\
\hline $\begin{array}{l}\text { 2. Handles embarrassment } \\
\text { constructively Helps each child feel } \\
\text { safe from judgment and } \\
\text { embarrassment. }\end{array}$ & $\begin{array}{l}\text { On occasion teases, dwells } \\
\text { on mistakes, praises in front } \\
\text { of others, downplays an } \\
\text { embarrassment, etc. }\end{array}$ & $\begin{array}{l}\text { Approaches children quietly } \\
\text { and unperturbed; discusses } \\
\text { issues privately. }\end{array}$ & $\begin{array}{l}\text { Models handling } \\
\text { embarrassment productively. }\end{array}$ & $\begin{array}{l}\text { Helps an embarrassed child } \\
\text { reflect and gain perspective } \\
\text { without minimizing } \\
\text { his/her/their feelings. }\end{array}$ \\
\hline $\begin{array}{l}\text { 3. Adapts activities of interest } \\
\text { Recognizes and capitalizes on } \\
\text { teachable moments. }\end{array}$ & $\begin{array}{l}\text { Occasionally tells a child } \\
\text { they aren't ready for an } \\
\text { activity of interest. }\end{array}$ & $\begin{array}{l}\text { Responds to children's } \\
\text { expressed interest in a topic, } \\
\text { activity, or material. }\end{array}$ & $\begin{array}{l}\text { Suggests alternatives for } \\
\text { work a child is interested in } \\
\text { but not yet ready for. }\end{array}$ & $\begin{array}{l}\text { Adapts an activity of interest } \\
\text { to a child's ability level. }\end{array}$ \\
\hline $\begin{array}{l}\text { 4. Values children's work spaces } \\
\text { Respects and cultivates respect for } \\
\text { each child's workspace. }\end{array}$ & $\begin{array}{l}\text { Moves children's work to a } \\
\text { new location without } \\
\text { obtaining agreement first. }\end{array}$ & $\begin{array}{l}\text { Asks permission before } \\
\text { touching or writing on } \\
\text { children's work. }\end{array}$ & $\begin{array}{l}\text { Helps children respect one } \\
\text { another's workspace. }\end{array}$ & $\begin{array}{l}\text { Introduces methods for } \\
\text { organizing and maintaining } \\
\text { an orderly work area. }\end{array}$ \\
\hline $\begin{array}{l}\text { 5. Addresses implicit bias Counters } \\
\text { implicit bias to provide every child } \\
\text { with an equitable experience. }\end{array}$ & $\begin{array}{l}\text { Believes he/she/they doesn't } \\
\text { have implicit bias without } \\
\text { examining one's internal } \\
\text { stereotypes. }\end{array}$ & $\begin{array}{l}\text { Learns about and begins to } \\
\text { examine one's own implicit } \\
\text { bias. }\end{array}$ & $\begin{array}{l}\text { Identifies blind spots that } \\
\text { hinder perceiving and } \\
\text { responding to children fairly. }\end{array}$ & $\begin{array}{l}\text { Uses data to assess if lessons } \\
\text { are given equitably. }\end{array}$ \\
\hline $\begin{array}{l}\text { 6. Supports social justice goals } \\
\text { Supports social justice with cultural } \\
\text { sensitivity and culturally responsive } \\
\text { teaching. }\end{array}$ & $\begin{array}{l}\text { Focuses solely on cultural } \\
\text { materials to address social } \\
\text { justice goals. }\end{array}$ & $\begin{array}{l}\text { Reflects a variety of cultures, } \\
\text { races, family makeup, etc., in } \\
\text { materials, and the classroom. }\end{array}$ & $\begin{array}{l}\text { Represents the culture of } \\
\text { each child when possible in } \\
\text { lessons, materials, and the } \\
\text { environment. }\end{array}$ & $\begin{array}{l}\text { Teaches about social justice } \\
\text { issues and engages children } \\
\text { in related activities. }\end{array}$ \\
\hline
\end{tabular}




\section{Professional Behavior}

\section{A. Demeanor}

1. Listens carefully Talks with attentively.

2. Dresses professionally Appearance is appealing and professional. Smiles often, is warm, and maintains a positive, relaxed attitude.

4. Respects children's personal space Assures respect for each child's contact and proximity preferences.

5. Provides appropriate feedback Responds to children in a sensitive and conscientious manner.

6. Connects with each child Builds a trusting, collaborative relationship with each child.

7. Fosters home and school partnerships Fosters ongoing, constructive home/school partnerships for each child. children at eye level and listens

3. Maintains a positive attitude

P
Unaware

Periodically focuses

conversing with a child.

Some clothing is best worn elsewhere, e.g., flip-flops, low necklines, showing the midriff. impatience, dislike, etc., toward a child.

Sometimes pulls, touches, or hugs a child without prior consent.

Sometimes uses sarcasm, off color jokes, statements that dampen enthusiasm, etc.

Occasionally views some children as slow, difficult, annoying, etc.

Interactions with families mostly occur during conferences. somewhere else while

At times conveys irritation,

\section{Beginning}

Communicates with children

at eye level.

Clothing is neat, clean, and in good repair.

Smiles frequently, and uses a constructive, upbeat tone of voice. appears comfortable to children (they don't lean away).

Uses encouragement and appropriate humor, e.g., funny stories, puns, wordplay.

Begins to establish a rapport with each child.

Gets to know families; promptly and respectfully addresses questions and concerns.
Talks at a distance that

\section{Developing}

Looks at children while listening with interest.

Accessories are limited, nonencumbering, and culturally appropriate.

Maintains a relaxed posture; seems to be having fun. another's personal space.

Provides feedback that is specific, descriptive, and constructive, e.g., "Wow, you counted then you..."

Works to help each child feel safe, important, and cared for.

Emphasizes children's strengths; notifies families of issues in a timely manner.
Helps children maintain one

\section{Maturing}

Listens to children with undivided attention in and outside of lessons.

Effort is made to look attractive and professional.

Movements convey patience, respect, warmth, and sensitivity.

Learns and respects the personal space preferences of each child.

Feedback is given equitably and reflects children's cultural norms.

\section{Uses reflection to} understand and support children who rub us the wrong way.

Promotes family involvem ent, helping each to feel connected and supported.

\begin{tabular}{|c|c|c|c|c|}
\hline B. Development & Unaware & Beginning & Developing & Maturing \\
\hline $\begin{array}{l}\text { 1. Shows professional commitment } \\
\text { Is an active, committed member of } \\
\text { the class and school community. }\end{array}$ & $\begin{array}{l}\text { Sometimes seems hesitant to } \\
\text { assume basic classroom } \\
\text { responsibilities. }\end{array}$ & $\begin{array}{l}\text { Is eager to give lessons and } \\
\text { assist children. }\end{array}$ & $\begin{array}{l}\text { Willingly assumes increased } \\
\text { classroom responsibility, e.g., } \\
\text { gives more complex lessons. }\end{array}$ & $\begin{array}{l}\text { Readily participates in } \\
\text { conferences, staff activities, } \\
\text { and school events. }\end{array}$ \\
\hline $\begin{array}{l}\text { 2. Wants to improve professionally } \\
\text { Indicates desire to improve and do } \\
\text { his/ her/their best professionally. }\end{array}$ & $\begin{array}{l}\text { Tends to receive feedback } \\
\text { reluctantly or resists } \\
\text { initiating change. }\end{array}$ & $\begin{array}{l}\text { Responds favorably to } \\
\text { constructive suggestions. }\end{array}$ & $\begin{array}{l}\text { Makes and implements a } \\
\text { plan of action to address } \\
\text { identified problems or issues. }\end{array}$ & $\begin{array}{l}\text { Recognizes when help is } \\
\text { needed, and seeks advice, } \\
\text { and support. }\end{array}$ \\
\hline $\begin{array}{l}\text { Practices self-care Engages in } \\
\text { ongoing self-care and rejuvenation. }\end{array}$ & $\begin{array}{l}\text { At times puts the needs of } \\
\text { others before one's own } \\
\text { needs. }\end{array}$ & $\begin{array}{l}\text { Makes time for sleep, } \\
\text { exercise, eating well, and } \\
\text { socializing. }\end{array}$ & $\begin{array}{l}\text { Maintains outside interests, } \\
\text { and prioritizes tasks when } \\
\text { stressed. }\end{array}$ & $\begin{array}{l}\text { Sets realistic goals, delegates } \\
\text { and organizes to help } \\
\text { maintain work/life balance. }\end{array}$ \\
\hline $\begin{array}{l}\text { 4. Engages in professional } \\
\text { development Engages in ongoing } \\
\text { professional development. }\end{array}$ & $\begin{array}{l}\text { Chooses not to participate in } \\
\text { professional development } \\
\text { activities. }\end{array}$ & $\begin{array}{l}\text { Actively engages in school } \\
\text { provided continuing } \\
\text { education. }\end{array}$ & $\begin{array}{l}\text { Participates in workshops, } \\
\text { action research, etc., to } \\
\text { develop professionally. }\end{array}$ & $\begin{array}{l}\text { Attends conferences, } \\
\text { seminars, etc., to support life } \\
\text { long learning. }\end{array}$ \\
\hline
\end{tabular}

